\title{
Genes associated with hypersensitive response (HR) in the citrus EST database (CitEST)
}

\author{
Simone Guidetti-Gonzalez ${ }^{1}$, Juliana Freitas-Astúa ${ }^{2,4}$, Alexandre Morais do Amaral ${ }^{3,4}$, \\ Natália F. Martins ${ }^{3}$, Angela Mehta ${ }^{3}$, Marilia Santos Silva ${ }^{5}$ and Helaine Carrer ${ }^{1}$ \\ ${ }^{1}$ Departamento de Ciências Biológicas, Escola Superior Luis de Queiróz, \\ Universidade de São Paulo, Piracicaba, SP, Brazil. \\ ${ }^{2}$ Embrapa Mandioca e Fruticultura Tropical, Cruz das Almas, BA, Brazil. \\ ${ }^{3}$ Embrapa Recursos Genéticos e Biotecnologia, Brasília, DF, Brazil. \\ ${ }^{4}$ Centro APTA Citros Sylvio Moreira, Instituto Agronômico de Campinas, Cordeirópolis, SP, Brazil. \\ ${ }^{5}$ Embrapa Cerrados, Planaltina, DF, Brazil.
}

\begin{abstract}
Plants are continuously exposed to pathogen attack, but successful infection is rare because they protect themselves against pathogens using a wide range of response mechanisms. One of them is the hypersensitive response $(\mathrm{HR})$, which is a form of cell death often associated with plant resistance to pathogen infection to prevent the spreadsebpg@cnpq.brsebpg@ cnpq.br of the potential pathogen from infected to uninfected tissues. Cell death is activated by recognition of pathogen-derived molecules by the resistance $(R)$ gene products, and is associated with the massive accumulation of reactive oxygen species (ROS), salicylic acid (SA), and other pro-death signals such as nitric oxide (NO). The analysis of the citrus EST (CitEST) database revealed the presence of putative genes likely to be involved in HR through their products, like metacaspases, lipoxygenases, phospholipases, pathogenesis-related proteins, glutathione transferases/peroxidases, enzymes involved in the phenylpropanoid pathway and in the formation and detoxification of ROS, as well as those involved in the formation and regulation of ion channels, SA and NO. By analysis of the EST database of Citrus, it was possible to identify several putative genes that code for key enzymes involved in HR triggering and also in plant defense against biotic and abiotic stress.
\end{abstract}

Key words: otic and abiotic stress response, plant-pathogen incompatible interaction, programmed cell death, plant disease resistance.

Received: July 21, 2006; Accepted: February 28, 2007.

\section{Introduction}

Plant-pathogen interactions involve complex, specific, and dynamic mechanisms. When a plant is resistant to a pathogen (incompatible interaction), its recognition often results in a hypersensitive reaction (HR), a rapid cell death of the plant tissues at the infection site that contributes to the limitation of growth and spread of the pathogen (Gabriel and Rolfe, 1990; Parker and Coleman, 1997; Lee and Hwang, 2005). It is generally believed that recognition of incompatible pathogens, via specific resistance genes encoded by the plant genome, leads to the activation of a number of different signaling mechanisms that initiate at the plasma membrane (Pontier et al., 2002).

Send correspondence to Helaine Carrer. Departamento de Ciências Biológicas, Escola Superior Luis de Queiróz, Universidade de São Paulo, Av. Pádua Dias 11, 13418-900 Piracicaba, SP, Brazil. E-mail: hecarrer@esalq.usp.br.
The initial events following the recognition of the pathogen elicitor by the plant are calcium influx, alkalinization of the extracellular space, protein kinase activation, production of reactive oxygen species (ROS) and nitric oxide (NO), and transcriptional reprogramming (Dangl and Jones, 2001). The $\mathrm{H}_{2} \mathrm{O}_{2}$ produced by the oxidative burst in the dark does not play an important role in the execution of cell death, but an early and massive production of fatty acid hydroperoxides by lipoxygenases has a prominent role in cell death (Montillet et al., 2005). NO and ROS could also contribute to rapid transcriptional activation of a battery of "defense genes" in and surrounding the infected cell. Some of these genes encode peroxidases, glutathione $S$-transferases, proteinase inhibitors, and various biosynthetic enzymes, such as phenylalanine ammonia lyase $(\mathrm{PAL})$, which is the first enzyme in the phenylpropanoid pathway and is involved in the synthesis of low molecular weight, antimicrobial compounds known as phytoalexins 
(Klessig et al., 2000). Other defense mechanisms that are activated include biosynthesis of salicylic acid, induction of ethylene biosynthesis, cell-wall strengthening, and lignification (Scheel, 1998; Lam et al., 2001). The oxidative burst leads to a HR and then to the establishment of systemic acquired resistance (SAR) (Rentel et al., 2004).

HR has been a source of interest and controversy since its recognition in 1915; however, in recent years, the combination of molecular genetics, computer-enhanced microscopy, new cytochemical techniques and a better understanding of plant signal transduction and cell biology have helped to unravel this apparently universal plant response (Heath, 2000).

A functional genomics project has been initiated to study the molecular characterization of the main biological and agronomical traits of citrus (Forment et al., 2005) and the present work also tries to help to uncover the genetic machinery of Citrus species. The objective of this work was to identify expressed sequence tags (ESTs) involved in the codification of key enzymes related to the HR in citrus plants. By searching the citrus EST database (CitEST), we describe putative pathways that may lead to HR in citrus plants.

\section{Materials and Methods}

In the Citrus EST Sequencing Project (Millennium Project-CNPq), various libraries of citrus cDNA were constructed with tissues from Citrus sinensis, C. reticulata, $C$. limonia, C. aurantifolia, C. aurantium, C. limettiodes, $C$. latifolia, $C$. sunki and Poncirus trifoliata, in different combinations of limiting factors (biotic and abiotic), physiological conditions (adult x juvenile) or tissue (leaf, bark, fruit, root, flower, and seed). The libraries description can be found in Targon et al. (this issue). The CitEST database contains over 181,000 sequenced ESTs (see CitEST: http:// biotecnologia.centrodecitricultura.br), which were used in this work.

The identification of the genes related to HR was performed by using keywords (metacaspases, calcium and potassium channels, NAD(P)H oxidase, peroxidases, superoxide dismutase, nitrate reductase, chorismate mutase, phenylalanine ammonia-lyase, cinnamic acid 4-hydroxylase, chalcone synthase, isochorismate synthase, lipoxygenase, phospholipase, glutathione transferase, glutathione peroxidase, chitinase, osmotin, thaumatin, permeatin) and by BLASTX searches with related sequences present in other species, like Arabidopsis thaliana, Lycopersicon esculentum (tomato), Oryza sativa (rice), Nicotiana tabacum (tobacco) and others in the CitEST database. Reads with E value $<10^{-10}$ were individually inspected, excluding sequences unrelated to the target enzyme, whereas the remaining sequences were clustered using the CAP3 (Huang and Madan, 1999). In order to analyze phylogeny among CitEST contigs and coding region of the proteins identified in the NCBI database of known HR genes, cladograms were made using ClustalW program (http:// www.ebi.ac.uk/clustalw/).

\section{Results and Discussion}

The clusterization of the reads identified using keywords and BLASTX with known HR genes from other plant species in the CitEST database resulted in 227 contigs and 174 singletons. Table 1 shows 18 proteins involved in the HR process identified in the CitEST, including the total number of contigs and singletons obtained. The presence of these proteins permitted inference of a putative pathway that leads to HR in citric plants.

The NCBI database (http://www.ncbi.nlm.nih.gov/) has 184,881 and 28,822 nucleotides sequences of Citrus and Poncirus species, respectively. Searches in this database revealed the presence of two sequences related to glutathione peroxidase, one peroxidase, two superoxide dismutase, five phenylalanine ammonia-lyase, three cinnamic acid 4-hydroxylase, three chalcone synthase, three lipoxygenase, four chitinase and one osmotin in Citrus sequences, while for the Poncirus species there are just one superoxide dismutase, two nitrate reductase and one glutathione transferase. Some HR genes were not identified in this database, such as metacaspase, calcium and potassium channel related proteins, nitrate reductase, isochorismate synthase, chorismate mutase, phospholipase and glutathione transferase, however they were identified in the CitEST database. According to these data, this work would be con-

Table 1 - Classes of HR proteins identified in CitEST database.

\begin{tabular}{lcc}
\hline \multirow{2}{*}{ HR Proteins } & \multicolumn{2}{c}{ Total number of } \\
\cline { 2 - 3 } & Contigs & Singletons \\
\hline Chalcone synthase & 4 & 12 \\
Chitinase & 29 & 24 \\
Chorismate mutase & 5 & 4 \\
Cinnamic acid 4-hydroxylase & 3 & 2 \\
Glutathione peroxidase & 10 & 2 \\
Glutathione transferase & 36 & 4 \\
Isochorismate synthase & 2 & 1 \\
Lipoxygenase & 16 & 18 \\
Metacaspase & 3 & 4 \\
Nitrate reductase & 3 & 1 \\
NADPH oxidase & 3 & 3 \\
PR-5-like proteins & 10 & 4 \\
Peroxidase & 52 & 42 \\
Phenylalanine ammonia-lyase & 4 & 7 \\
Phospholipase & 9 & 12 \\
Potassium channel & 17 & 16 \\
Superoxide dismutase & 19 & 16 \\
Two-pore calcium channel & 2 & 2 \\
\hline & & \\
& &
\end{tabular}


sidered the first attempt to catalog the majority of genes related to HR in Citrus and Poncirus species.

The identification of resistance $(R)$ genes that permits plants to perceive the pathogen invasion and trigger the ion flux, which culminates in HR, complements this work, and is reported in Guidetti-Gonzalez and Carrer (this issue). Several distinct MAPK (mitogen-activated protein kinases) cascades have been implicated in the regulation of plant disease resistance through signal transduction between perception of the elicitors and the activation of disease resistance genes. These MAPKs are reported in Mehta et al. (this issue). Besides, several pathogenesis related (PR) proteins are known to be expressed in the context of HR and usually act as antifungal factors at the end of the HR signaling cascade. Herein, the expression of two types of PR proteins typically presenting antifungal activity (chitinases and osmotins/thamatins/permeatins) were analyzed within the CiEST database. Campos et al. (this issue) are presenting a complete analysis of citrus PR proteins under biotic and abiotic stress.

The proteins involved in HR, found in the present work, are detailed below:

\section{Metacaspases}

Apoptosis in animals is characterized and commonly defined by the activation of a family of cysteine-dependent aspartate-specific proteases, or caspases (Pennell and Lamb, 1997). Caspases can proteolytically activate downstream caspases or cut various cellular substrates, leading to cell death (Utz and Anderson, 2000). Caspase homologues in plants have been reported and called metacaspase (Hoeberichts et al., 2003; Vercammen et al., 2004). In tomato, a metacaspase LeMCA1, is induced during infection of leaves with Botrytis cinerea (Hoeberichts et al., 2003). Searching within the CitEST, we found 18 reads that match with metacaspases of A. thaliana, L. esculentum and $O$. sativa, which formed three contigs and four singletons (Table S1). One of these singletons, with similarity of 3e- 84 to L. esculentum, came from P. trifoliata Citrus tristeza vi$r u s$-infected leaf library, which suggests involvement in plant disease resistance, as observed in other species (De Jong et al., 2000; Hoeberichts et al., 2003).

\section{Calcium and Potassium channels}

Some of the earliest signaling events detected during the HR include ion fluxes, influx of calcium and $\mathrm{H}^{+}$, and efflux of $\mathrm{K}^{+}$(Atkinson et al., 1990).

Calcium, as the divalent cation $\left(\mathrm{Ca}^{2+}\right)$, is an essential plant nutrient. It is required for structural roles in the cell wall and membranes, for inorganic and organic anion uptake in the vacuole, and as an intracellular messenger in the cytosol. Polarization or depolarization of the membrane voltage opens the gate subunits and allows calcium flow through the cell membrane. When calcium ions enter plant cells through $\mathrm{Ca}^{2+}$-permeable ion channels, tonoplast and/or endoplasmic reticulum, cellular responses to a diverse range of developmental cues and environmental challenges are initiated (White, 2000; Sanders et al., 2002).

The search for calcium channel sequences within the CitEST database revealed the presence of 15 reads (Table $\mathrm{S} 1)$. The clustering identified as potential calcium channels, two contigs and two singletons, contig 1 (C1) was mainly composed of $C$. sinensis sequences with only one sequence from $P$. trifoliata and one occurrence of $C$. reticulata. Contig 2 (C2) was mostly composed of $P$. trifoliata sequences (two reads) and one read from $C$. reticulata. Singletons were found in C. limonia and $P$. trifoliata.

Contig 1 showed $75 \%$ identity of deduced protein sequence with the Two-pore channel 1 (TPC1) from Arabidopsis thaliana (Furuichi et al., 2001). Contig 2 showed $61 \%$ amino acid identity with the Two-pore calcium channel TPCB1 from $N$. tabacum. One singleton is $74 \%$ identical to the $N$. tabacum TPC and the other is $50 \%$ identical to the tobacco TPC1B.

The wheat channel homologue to TPC1 from $A$. thaliana was cloned and expressed under abscisic acid (ABA) and various stress treatments indicating that these channels might be the first gate of control for several cell phenomena related to $\mathrm{Ca}^{2+}$ influx as cell signaling, homeostasis and stress response (Wang et al., 2005).

Potassium is the predominant inorganic ion of plant cells, where it plays a major role in contributing to cellular hydrostatic (turgor) pressure, growth, and responses to the environment (Michard et al., 2005).

The HLM1 gene encodes a member of the CNGC (cyclic nucleotide - gated channel - CNGC4) ion channel family (Maser et al., 2001). The study of this gene product showed that CNGC4 is permeable to both $\mathrm{K}^{+}$and $\mathrm{Na}^{+}$, is activated by cGMP and cAMP, and its expression is induced in response to pathogen infection and some pathogenrelated signals. So HLM1 may constitute a common downstream component of the signaling pathways leading to HR (Balague et al., 2003). In our analyses, we found only one singleton similar to HLM1 (6e-96), the other 15 singletons and 17 contigs showed similarity to other members of the CNGC family (Table S1), possibly with potassium channel activity. Our comparative analysis of the potassium channel revealed its presence in the $C$. reticulata, $C$. sinensis, $C$. latifolia, $C$. aurantifolia and $P$. trifoliata libraries. These results were expected because potassium is involved in wide environmental responses and is possibly involved in the citrus HR as well.

\section{Reactive oxygen species}

The generation of reactive oxygen species (ROS), such as singlet oxygen, superoxide anion radicals, hydrogen peroxide, and hydroxyl radicals is one of the earliest responses during HR just after ion fluxes (Atkinson et al., 1990). These ROS not only have direct antimicrobial activ- 
ity (Lamb and Dixon, 1997), but also act as signaling molecules leading to up- or down-regulation of numerous genes involved in plant defense responses such as the induction of defense-related genes and initiation of programmed cell death (PCD) at the site of the attempted infection (Neill et al., 2002; Apel and Hirt, 2004). This localized PCD generates a physical barrier restraining nutrient availability because of the rapid dehydration caused by tissue death (Parker and Coleman, 1997).

Plants have a number of ways of generating extracellular ROS (Bolwell and Wojtaszek, 1997). During the incompatible pathogen interaction, superoxides are produced enzymatically outside the cell and are rapidly converted to $\mathrm{H}_{2} \mathrm{O}_{2}$, which is able to cross the plasma membrane (Melillo et al., 2006). Cell wall-bound peroxidase (POXs) and a plasma membrane-bound NADPH oxidase are considered the major sources for ROS production as defense mechanisms during biotic stresses (Heath, 2000; Kawano, 2003; Melillo et al., 2006), even though there is evidence supporting a differential ROS generation for different stimuli as well (Bolwell, 1999).

The balance of production and detoxification of ROS is essential for aerobic life (Apel and Hirt, 2004) and the key enzymes or enzyme families involved in the production, as well as scavenging of ROS and induction of HR in plants are nicotinamide-adenine dinucleotide phosphate $[\mathrm{NAD}(\mathrm{P}) \mathrm{H}]$ oxidase, peroxidases and superoxide dismutases. Superoxide radicals generated by the one-electron reduction of molecular oxygen are rapidly converted within the chloroplast to hydrogen peroxide by $\mathrm{CuZn}$-superoxide dismutase (Asada, 1999). The superoxide dismutases (SODs) are extremely effective antioxidant plant enzymes (Skinner and Baek, 2006), since they dismutate two superoxide anions into $\mathrm{H}_{2} \mathrm{O}_{2}$ and $\mathrm{O}_{2}$ (Fridovich, 1991).

Three contigs and three singletons harboring $\mathrm{NAD}(\mathrm{P}) \mathrm{H}$ oxidase gene sequences were obtained from the CitEST database. The three contigs comprised 16, 4 and 5 reads, respectively. They were assembled with ESTs from both $C$. sinensis and $P$. trifoliata libraries. However contig 2 (C2) and contig 3 (C3) presented only reads from the leaf libraries, contig 1 (C1), with the largest number of reads, comprised sequences from fruit tissue as well. The three contigs contained partial gene sequences and exhibited similarity with NADPH oxidase protein from either Nicotiana sp. or A. thaliana as best BLASTX hits (Table S1).

Plants have multiple genes encoding peroxidases (Tognolli et al., 2002; Apel and Hirt, 2004). Therefore, as expected, a large number of peroxidase transcripts were identified, 568 reads total, which clustered in 52 contigs and 42 singletons (Table S1).

Several interesting inferences could be drawn from these sequences. Considering that glutathione S-transferase/peroxidase comprises a large number of reads, which are from all of the seven Citrus and Poncirus species and also the six tissues available at the CitEST, we can infer that the expression of these transcripts are constitutive not only in the genus Citrus but, likely, in other related rutaceae.

However, in a few cases, the specificity of the contigs is evident, with some particular conditions leading to the clustering of similar sequences in well-defined contigs. One of the contigs (C63) was composed of three C. limonia sequences, all of them were from the library constructed from roots undergoing water stress, suggesting that this transcript may code for a peroxidase involved in drought response. Interestingly, three contigs (C22, C64 and C65) were composed by reads from a library constructed from $C$. sinensis symptomatic for citrus variegated chlorosis (CVC), caused by Xylella fastidiosa, one of the most devastating diseases of the crop, indicating that peroxidases may be involved in the response of citrus to this particular biotic stress.

The multicopy pattern of superoxide dismutase $(S O D)$ gene observed in various hosts was also found within the CitEST database, which yielded 19 contigs and 16 singletons with similarity to translated SOD sequences (Table S1).

As in the peroxidases, at least one contig harbored 43 sequences from most of the species and tissues from where the libraries were constructed. Interestingly, no $S O D$ gene was found to be expressed in the flower tissue, but that might be due to the relatively low number of reads of this library $(4,330)$ compared to the others (Targon et al., this issue). On the other hand, some contigs comprised reads from one or few species. While three contigs (C3, C18 and C19) were formed of only Poncirus sp. reads, the other 11 were formed of only Citrus sp. sequences. Within these latter, some harbored sequences from a particular species (two contigs from $C$. reticulata alone, five from $C$. sinensis, and one from $C$. latifolia), suggest high specificity of these transcripts.

Likewise the peroxidases, but on a lower level, it was possible to determine some tissue-specificity of the SOD transcripts. At least six contigs (C3, C4, C12, C13, C18, and $\mathrm{C} 19$ ) harbored sequences only from the leaf libraries, while the other three (contigs C7, C9, and C16) were formed solely by reads from the fruit libraries. Furthermore, few contigs comprised reads from a particular condition. One of them (contig C12), of great interest, was composed of 39 reads from both the $C$. sinensis and $C$. reticulata leaf libraries infected with $X$. fastidiosa. This transcript was similar to a $\mathrm{Cu} / \mathrm{Zn}$ superoxide dismutase from $C$. sinensis (CAA03881.1) and, since the two species are susceptible and resistant to CVC, respectively, it is likely that such transcript is not involved in disease resistance, but in the response to this specific biotic stress.

\section{Nitric oxide}

Nitric oxide (NO) has well-known biological functions in mammals, but it was only recently recognized as a 
signal compound in plants (Zhao et al., 2005). In fact, it is now known that NO plays an important role in diverse physiological processes in plants (Grun et al., 2006). The Avr factors from pathogens stimulate NO production, which promotes disease resistance in plants, collaborating with ROS in the oxidative burst (Delledonne et al., 1998). The relative level of $\mathrm{NO}$ and $\mathrm{H}_{2} \mathrm{O}_{2}$ appears to be very important to HR-associated cell death in soybean cells (Delledonne et al., 2001) and it was observed that only the simultaneous increase of $\mathrm{NO}$ and $\mathrm{H}_{2} \mathrm{O}_{2}$ in tobacco cells induced typical programmed cell death (de Pinto et al., 2002).

Two potential enzymatic sources of NO in plants are NO synthase (NOS) and nitrate reductase (NR). NOS is a family of well characterized enzymes in mammalian cells (Desikan et al., 2002) that was found in several plants (Neill et al., 2002), and serves as a signal for plant growth, development, and defense (Delledonne et al., 1998; Klessig et al., 2000; Neill et al., 2002). NR is a central enzyme of nitrogen assimilation in plants (Lea, 1999; Kaiser et al., 2002), and is induced in potato tubers treated with either Phytophthora infestans or an elicitor derived from this oomycete pathogen (Yamamoto et al., 2003).

Despite the large number of citrus ESTs sequenced in the CitEST Project, we did not find reads similar to NOS, which suggests that the NO synthesis in these plants can be preferentially performed by NR. Within the CitEST database, three contigs and one singleton similar to plant nitrate reductase were assembled (Table S1). One of these contigs (C10), similar to Petunia $x$ hybrida and also Tilia platyphyllos $(\mathrm{e}$-values $=0.0)$ nitrate reductase, seems to be expressed especially within non-infected leaf tissue from $C$. reticulata and $P$. trifoliata, while the unique read from bark $P$. trifoliata is from Phytophthora-infected library. These results suggest that this contig has species- and tissue-specific expression, showing that the bark tissue of $P$. trifoliata may be involved in the production of NO for plant defense, as with potato tubers infected with $P$. infestans (Yamamoto et al., 2003).

Another contig (C11), similar to NR from Tilia platyphyllos (2e-152) presents reads solely from $C$. reticulata and a tendency of expression in Xylella fastidiosa-infected leaves (Figure 1a). This specific expression pattern suggests that this protein is important to plant defense specifically in $C$. reticulata. The third contig (C7) did not exhibit a species-specific expression, but comprised mainly sequences from the $C$. reticulata and $C$. sinensis leaf libraries infected with $X$. fastidios $a$, indicating that this transcript may be involved in the response to this biotic stress. Figure 2 shows the estimate of a phylogeny among contigs C7, C10 and C11, with nitrate reductase from Petunia x hybrida (gi|294113), Tilia platyphyllos (gi|24474445) and Ricinus communis (gi|11119240). As expected, it was observed that Contigs $\mathrm{C} 10$ and $\mathrm{C} 11$ are more closely related to each other and are related with Tilia platyphyllos and Petunia $x$ hybrida, and $\mathrm{C} 7$ is more closely related to Ricinus communis.

\section{Phenylpropanoid pathway}

In plants, the phenylpropanoid pathway is responsible for the synthesis of a wide variety of secondary metabolic compounds, including lignins, salicylates, coumarins, hydroxycinnamic amides, pigments, and flavonoids (Hwang et al., 2003).

In the plant phenylpropanoid pathway, chorismate mutase catalyses the reaction that forms phenylalanine, and the enzyme phenylalanine ammonia-lyase (PAL) deaminates phenylalanine to yield cinnamic acid (Gozzo, 2003; Kaneko et al., 2003). Several other enzymes are present in the phenylpropanoid pathway, with cinnamate 4-hydroxylase $(\mathrm{C} 4 \mathrm{H})$-the first cytochrome $\mathrm{P} 450$ upstream in this pathway - leading to the synthesis of a variety of compounds including lignin monomers, flavonoids, and furocoumarins (Morant et al., 2003; Gravot et al., 2004). Chalcone synthase (CHS) is an enzyme that catalyses the reaction that leads to the production of flavonoids and phytoalexins (Yang et al., 2002). The final substance produced by this pathway (4,2', 4', 6'-tetrahydroxychalcone) serves as the backbone for the production of a wide array of flavonoid compounds that function in such diverse roles as flower pigmentation, UV protection, signaling, male fertility, and defense against microbial pathogens (Winkel-Shirley, 2001).

Within the CitEST database, we found five contigs and four singletons similar to chorismate mutase (Table $\mathrm{S} 1$ ), some of them showed specific patterns of expression. The contig $4(\mathrm{C} 4)$ that is similar to $A$. thaliana chorismate mutase (accession number AAC73018) showed specific expression in the $C$. sinensis fruit, whereas the contig 6 (C6) (1e-67) (similar to accession number AAM61395) showed expression in $C$. reticulata fruits and in $C$. sinensis $X$. fastidiosa-infected leaves (Figure 1b). The other three contigs did not show an expression pattern, presenting reads from different libraries. Figure 3 shows a phylogeny analysis among contigs C4, C5, C6 and C7, and other chorismate mutase sequences from NCBI, showing coherence between contigs and the best hit in BLAST search (Table S1).

Four contigs and seven singletons were found in the search for phenylalanine ammonia-lyase (PAL) within the CitEST database (Table S1). The contig 10 presents high similarity (2e-107) with PAL from Nerium oleander and was expressed solely in P. trifoliata Phytophthora-infected bark (two reads), suggesting its importance in specific defense of this species. Another contig (C8), comprising sequences with similarity to that from $C$. limon, comprised 20 reads from different libraries. In $C$. sinensis, as in $C$. reticulata, reads showed a specific pattern of expression within $X$. fastidiosa-infected leaf libraries. However, PAL expression was also found in $C$. reticulata within the 


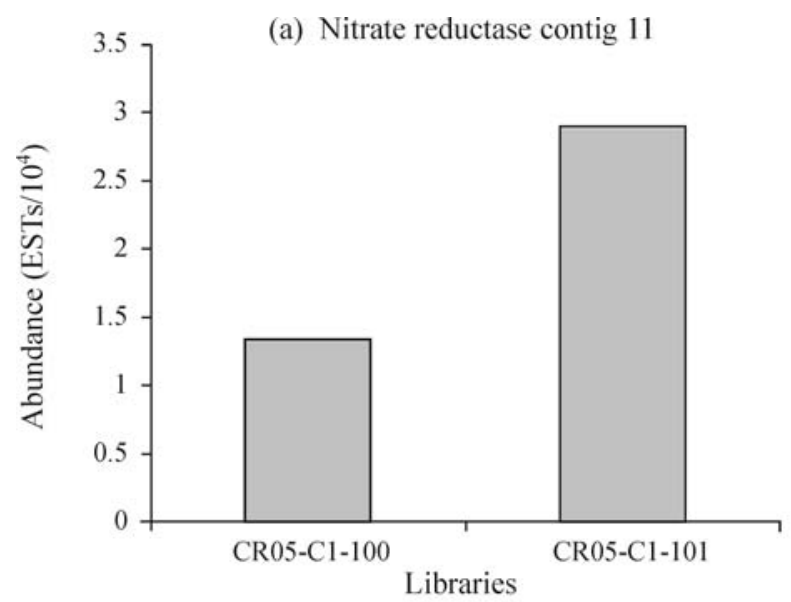

(c) Chalcone synthase contig 1

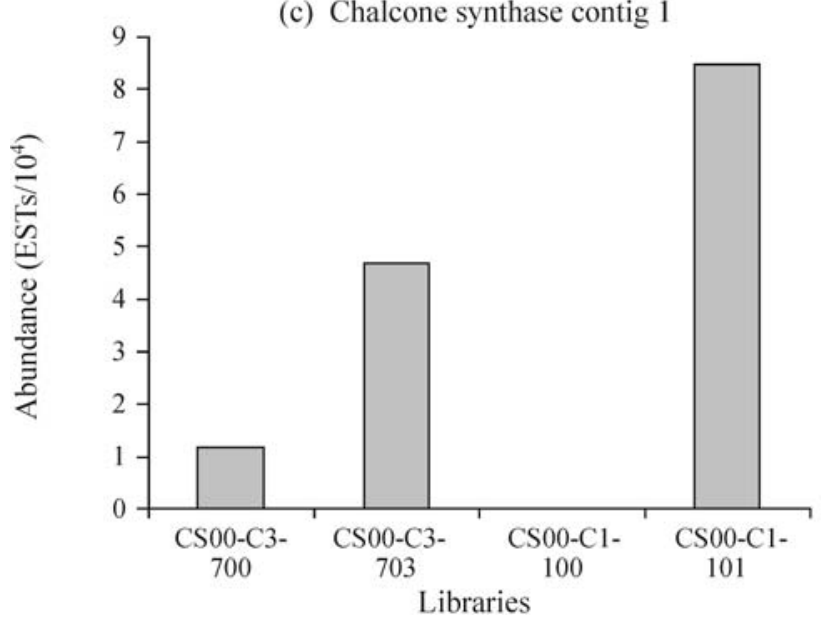

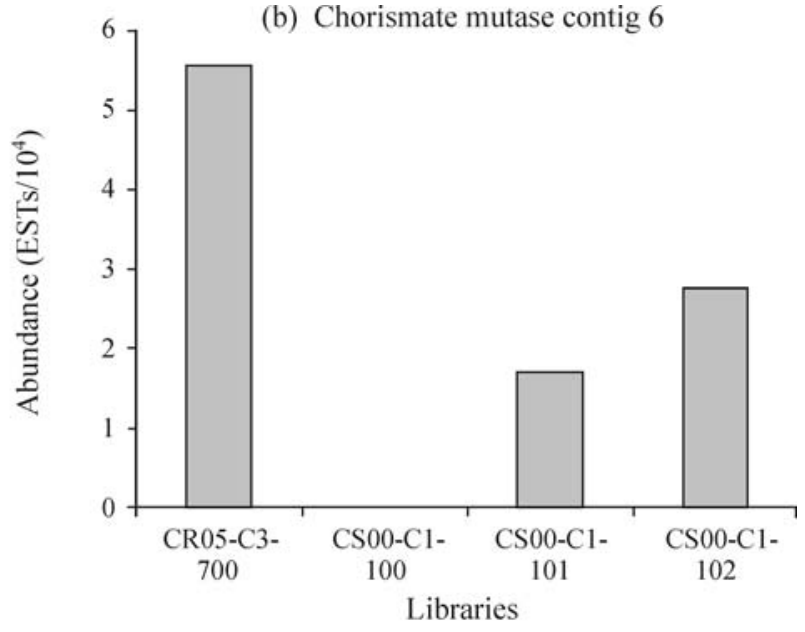

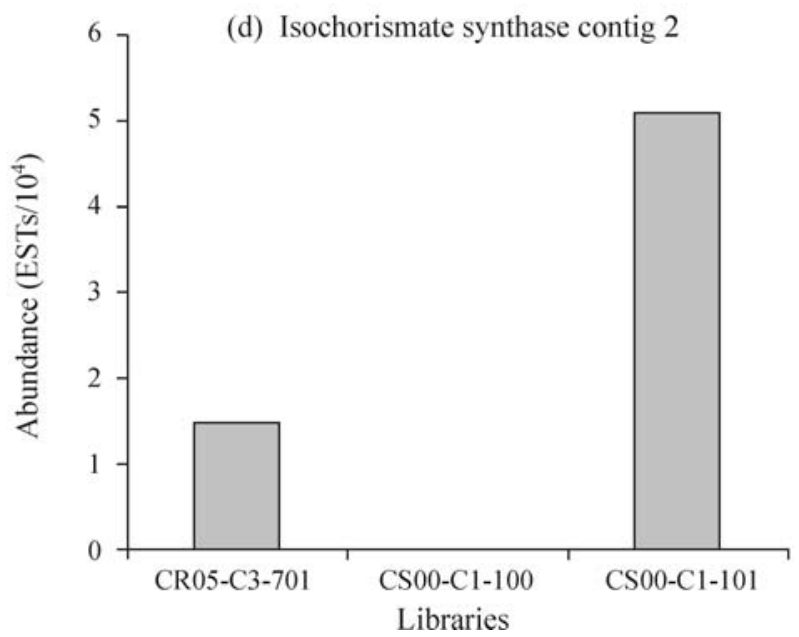

Figure 1 - Transformed data representing the relative abundance of EST by library, expressed in $10^{4}$ reads: (a) Nitrate reductase contig 11, (b) chorismate mutase contig 6, (c) chalcone synthase contig 1, (d) isochorismate synthase contig 2. Code of the libraries: CS: Citrus sinensis; CR: Citrus reticulata; C1: leaf cDNA; C3: fruit cDNA; 100: non-infected material; 101: infected with Xylella fastidiosa; 102: 30 days after X. fastidiosa infection; 700: stadium 1 of the fruit; 701: stadium 2 of the fruit; 703 stadium 4 of the fruit.

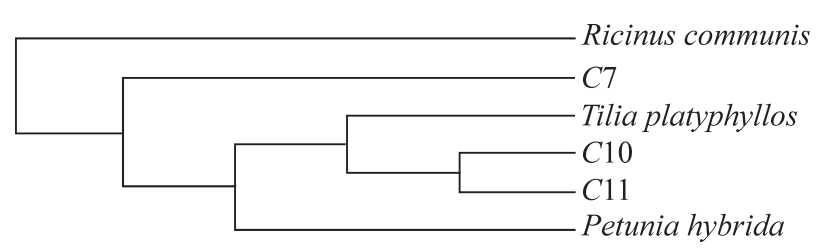

Figure 2 - Cladogram showing phylogeny relation among contigs 7, 10 and 11 with nitrate reductase from Petunia hybrida (gi|294113), Tilia platyphyllos (gi|24474445) and Ricinus communis (gi|11119240).

healthy fruit library. The contigs C3 (65 reads) and C9 (four reads) were similar to PAL from Citrus clementina x Citrus reticulata and Jatropha curcas, respectively, although they were highly similar to PAL (e-values $=0.0)$, they did not show any specific expression pattern, since they were formed by reads from a variety of libraries.

In a study with Valencia sweet orange, two cinnamic acid 4-hydroxylase (C4H) cDNAs were cloned and showed differential expression regulation (Betz et al., 2001). One

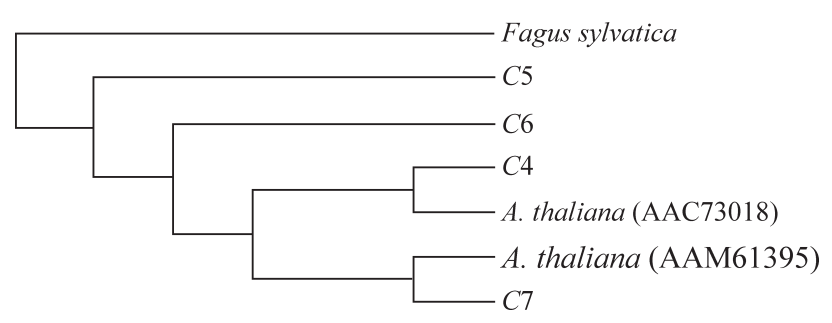

Figure 3 - Cladogram showing phylogeny relation among contigs 4, 5, 6 and 7 with chorismate mutase from Fagus sylvatica (ABA54871), Arabidopsis thaliana (AAC73018) and Arabidopsis thaliana (AAM61395).

of the cDNAs, $\mathrm{C} 4 \mathrm{H} 2$, appeared to be expressed constitutively and seemed to play the role of a 'housekeeping' gene in the phenylpropanoid pathway. Conversely, expression studies showed $\mathrm{C} 4 \mathrm{H} 1$ to be strongly wound-inducible, but even in wounded tissue it reached much lower levels of mRNA than C4H2 (Betz et al., 2001). 
Within the CitEST, we found three contigs and two singletons related to $\mathrm{C} 4 \mathrm{H} 2$ (Table $\mathrm{S} 1$ ). One of these contigs (C3) was assembled from 46 reads and showed $100 \%$ of identity with $\mathrm{C} 4 \mathrm{H} 2$, for which the majority reads originated from $C$. sinensis and C. reticulata in different stages of fruit development. Contig 1 (C1) showed $91 \%$ of identity with $\mathrm{C} 4 \mathrm{H} 2$ and was formed by 11 reads, mostly from $C$. sinensis (10 reads) in the early stages of fruit development and one read from the $P$. trifoliata Citrus tristeza virus-infected library. These results suggest a possible pattern of expression of this protein in the fruits of $C$. sinensis and C. reticulata. Moreover, a possible involvement in plant defense against pathogen in $P$. trifoliata cannot be excluded.

In contig 2 (C2), we observed $81 \%$ of amino acid identity with Medicago sativa $\mathrm{C} 4 \mathrm{H}$ protein (Table S1), in agreement with its pattern of expression during fruit ripening (Fahrendorf and Dixon, 1993), since the two reads of this contig were originated from the C. sinensis fruit libraries. Figure 4 shows the phylogeny pattern among contigs $\mathrm{C} 1, \mathrm{C} 2$ and $\mathrm{C} 3$, and cinnamic acid 4-hydroxylase from Citrus sinensis (AAF66066) and Medicago sativa (gi|166372); coherence can be observed with the best hit in BLAST search and the phylogenetic relationship.

Two cDNA clones encoding chalcone synthase (CHS) were isolated (CitCHS1 and CitCHS2) from citrus (Moriguchi et al., 1999). The accumulation of CitCHS2 mRNA was notably induced by embryogenesis but CitCHS1 mRNA was not. There was no detectable accumulation of flavonoid in the undifferentiated calli, but flavonoid accumulated after the morphological changes to embryoids. These results indicate that two CHS genes differentially expressed during citrus somatic embryogenesis and CitCHS2 may regulate the accumulation of flavonoids in citrus cell cultures (Moriguchi et al., 1999). Within CitEST, we found four contigs and 12 singletons related to chalcone synthase; among them, three contigs and eight singletons related to CitCHS2. Contig 3 (C3) is formed by 75 reads that mostly came from $C$. sinensis fruits in the early stages of development and is $100 \%$ identical to the most homologous BLAST hit (C. sinensis). Contig 4 (C4) was composed of 54 reads mostly from $C$. reticulata in the early stages of the fruit development and shares $92 \%$ identity with $C$. sinensis $\mathrm{CHS}$. Finally, another contig (C1) was formed by nine $C$. sinensis reads and presented a tendency of expression in early stages of $X$. fastidiosa-infected leaves

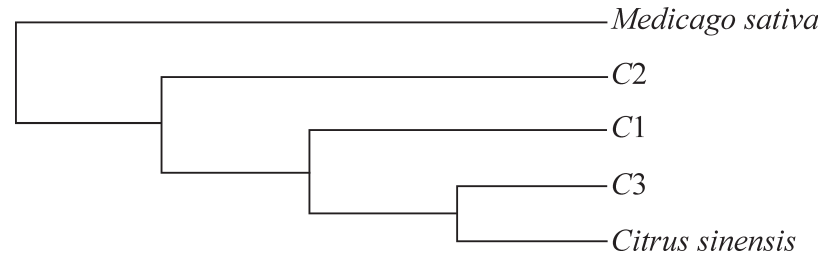

Figure 4 - Cladogram showing phylogeny relation among contigs 1, 2 and 3 with cinnamic acid 4-hydroxylase from Citrus sinensis (AAF66066) and Medicago sativa (gi|166372).
(Figure 1c), and was 79\% identical to C. sinensis CHS from NCBI. The singletons related to CHS came especially from C. sinensis and C. reticulata fruit libraries. Figure 5 shows the expected phylogeny relationship between these contigs and chalcone synthase from Citrus sinensis (BAA81664) and Betula pendula (CAA71904).

These results indicate a possible presence of at least two CHS genes in C. sinensis that are expressed during fruit development as shown in other species (Aharoni and O'Connell, 2002; Kumar and Ellis, 2003). In addition, other CHSs may be involved in citrus response to pathogens. For more information of flavonoid biosynthesis, see Lucheta et al. (this issue).

\section{Salicylic acid}

The involvement of salicylic acid (SA) as a signal molecule for plant defense has been extensively studied (Shah and Klessig, 1999; Shah, 2003; Stout et al., 2006). SA quickly accumulates at the site of infection during pathogen attack and plant HR, and it spreads to other parts of the plant to induce a wide range of defense responses (Zhao et al., 2005). Besides inducing PR protein genes, SA is assumed to act before the divergence of the two metabolic branches leading to the phenylpropanoid pathway and the activation of the oxidative burst, respectively. In this way, SA amplifies its own synthesis, which, in addition, is stimulated by $\mathrm{H}_{2} \mathrm{O}_{2}$ (Gozzo, 2003; Zhao et al., 2005).

Previous work has suggested that plants synthesize SA from phenylalanine utilizing chorismate mutase (Gozzo, 2003). However, evidence showed that, in the chloroplast of Arabidopsis, SA is synthesized from isochorismate catalysed by isochorismate synthase. This route, typical of bacteria, seems to be required even in other plants to produce SA for defense against pathogens (Métraux, 2002; Gozzo, 2003).

Although evidence from tobacco and potato would indicate that salicylic acid in plants is derived from phenylalanine via benzoic acid, catalysed by benzoic acid 2-hydroxylase (Yalpani et al., 1993; Coquoz et al., 1998) in citrus SA, formation seems to occur via the isochorismate route since the benzoic acid 2-hydroxylase was not found within the CitEST database.

Analysis within CitEST resulted in two contigs and one singleton similar to isochorismate synthases from $M$.

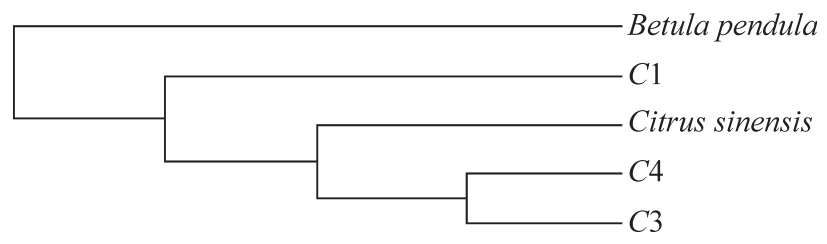

Figure 5 - Cladogram showing phylogeny relation among contigs 1, 3 and 4 with chalcone synthase from Citrus sinensis (BAA81664) and Betula pendula (CAA71904). 
truncatula, Capsicum annuum and Catharanthus roseus (Table S1). Only one contig (C2), similar to $M$. truncatula isochorismate synthase, showed a specific pattern of expression, presenting a tendency to be expressed in $C$. sinensis leaves, in the early stage of $X$. fastidiosa infection (Figure 1d). This result may suggest that this contig was formed by a transcript that codes for a protein involved in the production of SA upon plant infection by a pathogen.

\section{Lipoxygenases}

Lipoxygenases (LOXs) constitute a family of enzymes that deoxygenate polyunsaturated fatty acids containing cis, cis-1,4-pentadiene structure. The hydroperoxides produced by the LOX reaction are converted into a series of compounds involved in several physiological processes including growth, fruit ripening and response to biotic and abiotic stresses (Hildebrand et al., 1989; Gardner, 1991; Siedow, 1991; Brash, 1999). The most common substrates for plant LOXs are linoleic and linolenic acids, which are important constituents of plant membrane phospholipids. Plant LOXs are classified according to their positional specificity of linoleic or linolenic acid oxygenation, which occurs either at the C-9 or at the C-13 of the hydrocarbon backbone of the fatty acid. Therefore, these LOXs are often referred to as 9-LOXs or 13-LOXs.

Regarding sequence similarity, plant LOXs can be classified into two gene subfamilies. Enzymes with no transit peptide share a similarity higher than $75 \%$ with one another and are designated type 1-LOXs. The other subfamily, called type 2-LOX, contains a putative chloroplast transit peptide sequence and shares a sequence similarity of approximately $35 \%$ with each other (Feussner and Wasternack, 2002). In C. jambhiri, a LOX containing typical features of a transit peptide for chloroplastic targeting has been identified and expressed upon wounding and inoculation with nonpathogenic isolates of Alternaria alternata (Gomi et al., 2002b).

The analysis of the CitEST database revealed 323 sequences related to lipoxygenases, which formed 16 contigs and 18 singletons. The best hit in a BLASTX search as well as the homologous organism are shown in Table S1. The data available from the CitEST database does not allow us to classify the LOXs found and further studies are necessary to characterize the different citrus LOXs. Moreover, most contigs and singletons were incomplete and therefore a classification of the LOXs encountered, based solely on partial sequence comparison, may be premature. The three largest contigs obtained $(\mathrm{C} 3, \mathrm{C} 7$ and $\mathrm{C} 11)$ revealed deduced amino acid sequences of 921, 945 and 900 amino acids, respectively. The comparison of these sequences with those of the 8 other LOXs showed high similarity to the citrus LOXs (Table S1) revealed that the sequence of contig 7 presented an exclusive amino acid insertion sequence at po- sitions 574 to 606 . Contig 7 was formed by reads from healthy and $X$. fastidiosa-infected leaves of $C$. reticulata as well as $X$. fastidiosa-infected leaves of $C$. sinensis and showed $73 \%$ identity with lox 1 of Sesbania rostrata. Contig 3 showed $71 \%$ identity with a lox 2 of Zantedeschia aethiopica and contig 11 showed $78 \%$ identity with a lox of C. jambhiri. Contigs 3 and 11 represent complete sequences of the lox gene.

Some 9-LOXs have been associated to plant resistance and lipid peroxidation, which is involved in membrane damage and HR (Rance et al., 1998, Kolomiets et al., 2000; Jalloul et al., 2002). The biosynthesis of oxygenated unsaturated fatty acids via LOX pathway may be important for plant defense against pathogen attack (Peng et al., 1994). Most of the reads showing similarity to LOXs were obtained from pathogen-infected or fruit libraries. LOXs were highly expressed in the early stages of $X$. fastidios $a$ infected libraries of sweet orange ( $C$. sinensis) and mandarin (C. reticulata) (up to 30 days after inoculation-DAI). Some ESTs associated with lipoxygenase were also observed in C. reticulata up to 60 DAI. Several studies have reported that LOX activity in plants is higher and more rapid upon infection of avirulent pathogens as compared to virulent pathogens (Ocampo et al., 1986; Yamamoto and Tani, 1986; Siedow, 1991; Melan et al., 1993). C. reticulata is resistant to $X$. fastidiosa and, as expected, a higher expression of LOX was observed in $X$. fastidiosa-infected mandarin plants. LOX was also expressed in $C$. sinensis and $P$. trifoliata libraries infected with Citrus leprosis virus (CiLV) and Citrus tristeza virus (CTV), respectively. $P$. trifoliata is resistant to CTV and therefore the expression of LOX in this interaction was expected.

Several fruit ESTs associated with LOX were also identified within the CitEST database. The role of LOX in fruit development has been well documented (Griffiths et al., 1999; Chen et al., 2004a). LOXs play an important role in the production of volatile molecules that can influence flavor and aroma of many plant products (Robinson et al., 1995). LOXs can also alter shelf life and organoleptical and nutritional characteristics of plant products (Robinson et $a l ., 1995)$. These are important features for the citrus industry, since fruit quality is essential for juice production as well as for the commercialization of fresh fruits.

Three $C$. limonia EST sequences related to LOX were also expressed during water stress. Membranes are main targets of degradative processes induced by drought and lipid peroxidation is one of the most important causes of cell deterioration, resulting in changes in the composition of fatty acids that affect the structural and functional properties of cell membranes (Smirnoff, 1993; Asada, 1999). The expression of LOXs during drought has been reported (Gigon et al., 2004; Sofo et al., 2004); however, little is known about the relationship between drought stress and LOX activity. Further studies are necessary to better understand the function of citrus LOXs in drought response. 


\section{Phospholipases}

Phospholipases (PLs) in plants are known to be involved in several cellular responses, including plant growth, development, and responses to stress and defense. PLs play a pivotal role in the plant response via lipids pathway. The superfamily is involved in processes such as cytoskeletal rearrangement, membrane trafficking and degradation (Meijer and Munnik, 2003; Wang, 2004). Several studies have associated PL activity to stress response and defense, and the involvement of PLs and other enzymes in cell death has also been reported (Spiteller, 2003; Wang, 2005).

Plant PLs are classified according to their site of hydrolysis on phospholipids as phospholipase $\mathrm{A}_{1}\left(\mathrm{PLA}_{1}\right)$, phospholipase $\mathrm{A}_{2}\left(\mathrm{PLA}_{2}\right)$, phospholipase $\mathrm{C}$ (PLC), and phospholipase D (PLD).

The analysis within the CitEST database revealed sequences related to PLs. The assembling of the reads (E-value $<-10$ ) provided 9 contigs and 12 singletons with E-value $<-10$. The best hit in a BLASTX search as well as the homologous organism are shown in Table S1.

The phospholipase A (PLA) activity increased rapidly and systemically in response to wounding by attack of herbivores in leaves of tomato plants (Narvaez-Vasquez et al., 1999). Multiple secretory-phospholipase $\mathrm{A}_{2}\left(\mathrm{sPLA}_{2}\right)$ genes have been also identified in plants (Lee et al., 2005) and within the CitEST database, four reads were identified with high similarity to $\mathrm{PLA}_{2}$. The clusterization provided only one contig that was confirmed to be $75 \%$ identical to a rice $\mathrm{PLA}_{2}$ form, and this contig was formed by reads from healthy $C$. sinensis and C. aurantifolia libraries. This $\mathrm{PLA}_{2}$ contig contains twelve conserved cysteine residues and sequences that are likely to represent the $\mathrm{Ca}(2+)$-binding loop and active-site motif, which are characteristic of animal $\mathrm{PLA}_{2} \mathrm{~S}$. In the CitEST project, the PLA $\mathrm{A}_{2}$ identified was sequenced from bark tissue, probably indicating a secretory possibility and a defense response in plant to a variety of stimuli including biotic and abiotic stresses (Lee et al., 2005).

Under the control of cell surface receptors, the phosphoinositide-specific PLC isozymes hydrolyze the highly phosphorylated lipid phosphatidylinositol 4,5-bisphosphate $\left[\mathrm{PI}(4,5) \mathrm{P}_{2}\right]$, generating two intracellular products: inositol 1,4,5-trisphosphate ( $\operatorname{InsP}_{3}$ ), which is an universal calcium-mobilizing second messenger; and diacylglycerol, which is an activator of protein kinase $\mathrm{C}$ (Rebecchi and Pentyala, 2000). Evidence suggests that $\mathrm{InsP}_{3}$ may be involved in the signal transduction pathway for the development of the HR of $C$. lemon against $A$. alternata (Ortega and Perez, 2001). A search within the CitEST identified reads homologous to PLC genes. Clustering of these reads resulted in five contigs and nine singletons. The similarity among the deduced PLC proteins found ranged from 59\% to $73 \%$ identity to PLC from $A$. thaliana, O. sativa, Nicotiana rustica, and Glycine max. The most representa- tive group for PLC was contig 1, which was formed by reads from the libraries, bark and leaves of healthy $C$. sinensis and from $C$. sinensis $X$. fastidiosa-infected leaves.

PLD mediates the hydrolysis of membrane lipids and diacylglycerol-kinase-mediated phosphorylation of diacylglycerol (Wang, 2002). The expression of several PLD genes has been extensively reported in plant defense induced by the elicitor treatment as well as pathogen infection (Laxalt et al., 2001; De Torres et al., 2002). The PLD group was present in 14 reads clustered into three contigs within CitEST. The PLD genes identified were classified as different isoforms related to the $A$. thaliana (AAP42742.1) PLD protein. The CitEST PLDs were 80 to $83 \%$ identical to their orthologues. The largest PLD was also formed by reads from healthy $C$. sinensis.

Analysis of the CitEST database revealed the presence of several citrus PLs; however, since most contigs and singletons are incomplete, it was not possible to unequivocally classify them within the family. Further studies are necessary to better understand the genetic and biochemical heterogeneity of PLs and to relate the function of citrus PLs in HR.

\section{Glutathione transferases and Glutathione peroxidases}

Plant tissues contain several ROS scavenging enzymes (like glutathione peroxidase) and detoxifying lipid peroxidation products (like glutathione S-transferases and phospholipid-hydroperoxide glutathione peroxidase) (Chen et al., 2004b), which protect cells from ROS and damage from stress conditions.

By using an in-silico analysis of the CitEST database, we have identified 36 contigs and four singletons related to glutathione transferase (GST) genes (Table S1). Taking into consideration that the CitEST database was constructed based on a number of ESTs produced during different stages of the development and challenges, it is obvious that, as seen in other plant species (Sappl et al., 2004), several mechanisms are acting to induce citrus GSTs.

By combining keyword and BLASTX searching within the CitEST database with the sequence from public database that showed the best match with citrus sequences, we found full-length genes with high homology to GST 22 from soybean (McGonigle et al., 2000). Whether this putative gene plays a role in stress tolerance remains to be experimentally demonstrated in plant species, including citrus. In addition, we found full-length copies of LeGSTT3, a GST protein from tomato that was found to protect yeast cells from $\mathrm{H}_{2} \mathrm{O}_{2}$-induced oxidative stress (Kilili et al., 2004). This indicates that the putative citrus genes could play a role in cell protection from pro-oxidant-induced cell death.

Glutathione peroxidases (GPX) are enzymes that reduce organic hydroperoxides produced during oxidative stress. The over-expression of a GPX inhibited oxidative 
stress - induced PCD in tomato (Chen et al., 2004b). It is strongly suggested that specific GPXs, such as Phospholipid Hydroperoxide GPX (PHGPX), play a specific role in ROS; however, their specific role in plants remains to be elucidated (Milla et al., 2003; Chen et al., 2004b). PHGPX functions, in the removal of phospholipid hydroperoxides, are generated as products of lipoxygenase catalysed oxygenation of fatty acids (Ursini et al., 1985).

The analysis of the CitEST database also revealed sequences related to GPXs, which formed 10 contigs and 2 singletons (Table S1). The analysis of these sequences shows GPX and PHGPX similar to the ones found in orange, pea, Momordica charantia, chickpea, and Arabidopsis.

At least two copies of a gene found in this study code for the PHGPX that was experimentally found to be responsible for salt-stress signaling in citrus (Holland et al., 1993; Avsian-Kretchmer et al., 2004).

As compared to other stress-related genes found in this broad-scale search, an observation that emerged was the proportion of genes that code for GPX in citrus. On the basis of these results, it is suggested that GPX is an enzyme that shows a low number of isoforms and/or copies in the genome of citrus and, probably, plays a role in a condition not strongly induced in this study.

\section{Pathogenesis-related proteins}

The induction of PR proteins is triggered stereotypically in plants by infection with fungal, bacterial, and viral pathogens, and is part of a more general response to biotic and abiotic stress (Datta and Muthukrishnan, 1999). PR proteins comprise a group of 17 protein classes (Christensen et al., 2002), most of which present antifungal activity, such as the PR-3, PR-4, PR-8 and PR-11 proteins (also known as chitinases) and the PR-5 proteins (also known as osmotins, permatins or thaumatins).

The chitinases, which are vacuolar PR proteins, act in concert to defend against a specific class of pathogens, fungi (Wirdnam et al., 2004). Moreover, there is also an indication that chitinases may act as lysozymes, by degrading bacterial cell walls (Tiffin, 2004). This class of proteins can be induced by ethylene treatment and in association with HR (Leubner-Metzger and Meins, 1999).

The analysis of the CitEST database revealed several reads related to chitinases, which formed 29 contigs and 24 singletons (Table S1). The analysis of these sequences shows various acidic classes I and II chitinases that match with citrus libraries from elsewhere. In addition, we found a number of sequences that relate to chitinase, in general, from other plant species such as A. thaliana, Tulipa bakeri, Hevea brasiliensis, Gossypium hirsutum, and N. tabacum. In rough lemon (C. jambhiri), the expression of the two acidic chitinases (I and II) was not constitutive and accumulated in leaves two hours after induction by wounding or inoculation with non-pathogenic isolates of $A$. alternata
(Gomi et al., 2002a). Our results reveal that a number of acidic class I and II chitinases are expressed in citrus. However, it remains unclear whether the citrus chitinases found in our study refer to isoforms of the same gene.

The PR-5 proteins are expressed in response to abscisic acid, ethylene, auxin, salinity, lack of water, cold, UV light, wounding, viral, fungal and oomycetal infection (Nelson et al., 1992; Zhu et al., 1995; Sato et al., 1996). Within the CiEST database, we found 63 unique reads related to PR-5-like proteins, clustered into 10 contigs and four singletons (Table S1). These singletons encode a 219amino acid ORF homologous to a sunflower (H. annuиs) PR-5-like protein, a 190-amino acid ORF homologous to a turnip (B. rapa) PR-5-like protein, as well as a 182- and a 280-amino acid ORF, both homologous to a tobacco $(N$. tabacum) PR-5-like protein (Table S1). These singletons were originated from fruit libraries, from CTV-infected leaf libraries or from $X$. fastidiosa-infected leaf libraries, either from C. reticulata, C. sinensis or from P. trifoliata origin. The 10 PR-5-like contigs were assembled from two up to 13 reads each, mainly from the fruit libraries, but also from seed, bark, and flower libraries. Despite the fact that PR-5 proteins are expressed also in response to biotic stress, there were only five reads composing contigs which were originated from leaves infected either with $X$. fastidiosa or with CTV. Moreover, the majority of the PR-5-like reads forming contigs were from $C$. sinensis origin, secondarily from $C$. reticulata or $P$. trifoliata and seldomly from $C$. aurantifolia or $C$. aurantium. Two contigs homologous to tomato PR-5-like proteins, one homologous to an Arabidopsis PR-5-like protein (accession NP_173261), one homologous to a cultivated apple PR-5like protein and one homologous to a grape PR-5-like protein presented complete coding sequences when aligned with the best hit in BLASTX search. As expected, a CitEST contig homologous to a $C$. sinensis PR-5-like protein (accession AAC02549; Table S1) presented high amino acid identity (97\%). The 14 PR-5-like clusters found within the CitEST database, i.e., 10 contigs and the four singletons, were considerably similar (from $73 \%$ to $97 \%$ similarity) to their corresponding most homologous amino acid sequences (Table S1).

To conclude, the CitEST database is considerably representative of citrus PR-5-like sequences, expressed in various biological situations, tissues and citrus species. Unexpectedly, within the CitEST database, no PR-5-like sequences associated with drought stress or with infection by Phytophthora parasitica were found. Surprisingly, there were only seven reads found, out of 63 reads in total, which originated either from $X$. fastidiosa infected-leaves or from CTV infected-leaves. Although most of the PR-5-like reads found within the CitEST database are associated with abiotic stress and plant development processes, these sequences potentially encode PR-5 proteins involved also in citrus HR. Therefore, the possible role of the CitEST PR- 
5-like clusters in HR must be demonstrated experimentally. Further investigation is also necessary to clone complete citrus PR-5-like sequences, to validate their biological function and to better characterize their expression patterns under biotic and abiotic stress conditions.

\section{Concluding Remarks}

Despite a large number of potential pathogens that attempt to infect cultivated plants, disease is not the rule. Plants have an arsenal of mechanisms to defend themselves against pathogen invasion. One of these strategies is the expression of HR genes, elicited when resistant hosts are infected by incompatible races of a pathogen. It is characterized by localized cell death at the site of attempted infection, generating a physical barrier that restricts nutrient availability to the pathogen and prevents the dispersion of the pathogen to uninfected tissues. HR has been investigated extensively, and the increase of genomic sequences available has made it possible to indicate the existence of homologous genes in all plant species by in silico analysis. Moreover, the use of tools to search for sequence similarities at the amino acid level can reveal the overall patterns of gene network related to HR responses. In the present work, we tried to uncover the pathways that may lead to HR in citrus, based on the CitEST database. We found putative deduced proteins that can be important for HR and thus we have shown the putative pathways involved in this process. However, further studies are necessary to confirm the functions of these proteins and to better understand the genetic and biochemical network in citrus HR. To our knowledge, this is the first genome study that attempts to identify genes involved in HR in citrus plants. Functional characterization of them may contribute for the development of molecular tools to overcome economically important citrus diseases.

\section{Acknowledgments}

The authors would like to thank CNPq/ Millennium Institute (62.0054/01-8) for financially supporting this work and FAPESP for financial support of S. G.-G. $(05 / 58117-4)$.

\section{References}

Aharoni A and O'Connell AP (2002) Gene expression analysis of strawberry achene and receptacle maturation using DNA microarrays. J Exp Bot 53:2073-2087.

Apel K and Hirt H (2004) Reactive oxygen species: Metabolism, oxidative stress, and signal transduction. Annu Rev Plant Biol 55:373-379.

Asada K (1999) The water-water cycle in chloroplasts: Scavenging of active oxygens and dissipation of excess photons. Annu Rev Plant Physiol Plant Mol Biol 50:601-639.

Atkinson MM, Keppler LD, Orlandi EW, Baker CJ and Mischke CF (1990) Involvement of plasma membrane calcium influx in bacterial induction of the $\mathrm{K}^{+} / \mathrm{H}^{+}$and hypersensitive responses in tobacco. Plant Physiol 92:215-221.
Avsian-Kretchmer O, Gueta-DahanY, Lev-Yadun S, Gollop R and Ben-Hayyim G (2004) The salt-stress signal transduction pathway that activates the gpx1 promoter is mediated by intracellular $\mathrm{H}_{2} \mathrm{O}_{2}$, different from the pathway induced by extracellular $\mathrm{H}_{2} \mathrm{O}_{2}$. Plant Physiol 135:1685-1696.

Balague C, Lin B, Alcon C, Flottes G, Malmstrom S, Kohler C, Neuhaus G, Pelletier G, Gaymard F and Roby D (2003) HLM1, an essential signaling component in the hypersensitive response, is a member of the cyclic nucleotide-gated channel ion channel family. Plant Cell 15:365-379.

Betz C, McCollum TG and Mayer RT (2001) Differential expression of two cinnamate 4-hydroxylase genes in 'Valencia' orange (Citrus sinensis Osbeck). Plant Mol Biol 46:741-748.

Bolwell GP (1999) Role of active oxygen species and NO in plant defence responses. Curr Op Plant Biol 2:287-294.

Bolwell GP and Wojtaszek P (1997) Mechanisms for the generation of reactive oxygen species in plant defence: A broad perspective. Physiol Mol Plant Path 51:347-366.

Brash AR (1999) Lipoxygenases: Occurrence, functions, catalysis and acquisition of substrate. J Biol Chem 274:2367923682.

Chen G, Hacket R, Walker D, Taylor A, Lin Z and Grierson D (2004a) Identification of a specific isoform of tomato lipoxygenase (TomloxC) involved in the generation of fatty acid-derived flavor compounds. Plant Physiol 136:26412651.

Chen S, Vaghchhipawala Z, Li W, Asard H and Dickman MB (2004b) Tomato phospholipid hydroperoxide glutathione peroxidase inhibits cell death induced by bax and oxidative stresses in yeast and plants. Plant Physiol 135:1630-1641.

Christensen AB, Cho BHO, Næsby M, Gregersen PL, Brandt J, Madriz-Ordeñana $\mathrm{K}$, Collinge DB and Thordal-Christensen $\mathrm{H}$ (2002) The molecular characterization of two barley proteins establishes the novel PR-17 family of pathogenesisrelated proteins. Mol Plant Pathol 3:135-144.

Coquoz JL, Buchala A and Metraux JP (1998) The biosynthesis of salicylic acid in potato plants. Plant Physiol 117:1095-1101.

Dangl JL and Jones JD (2001) Plant pathogens and integrated defence responses to infection. Nature 411:826-833.

Datta SK and Muthukrishnan S (1999) Pathogenesis-Related Proteins in Plants. CRC Press LLC, Boca Raton, 290 pp.

De Jong AJ, Hoeberichts FA, Yakimova ET, Maximova E and Woltering EJ (2000) Chemical-induced apoptotic cell death in tomato cells: Involvement of caspase-like proteases Planta 211:656-662.

Delledonne M, Xia Y, Dixon RA and Lamb C (1998) Nitric oxide functions as a signal in plant disease resistance. Nature 394:585-588.

Delledonne M, Zeier J, Marocco A and Lamb C (2001) Signal interactions between nitric oxide and reactive oxygen intermediates in the plant hypersensitive disease resistance response. Proc Natl Acad Sci USA 98:13454-13459.

de Pinto M, Tommasi F and De Gara L (2002) Changes in the antioxidant systems as part of the signaling pathway responsible for the programmed cell death activated by nitric oxide and reactive oxygen species in tobacco bright-yellow 2 cells. Plant Physiol 130:698-708.

Desikan R, Griffiths R, Hancock J and Neill S (2002) A new role for an old enzyme: Nitrate reductase-mediated nitric oxide generation is required for abscisic acid-induced stomatal 
closure in Arabidopsis thaliana. Proc Natl Acad Sci USA 99:16314-16318.

De Torres Z, Fernandez-Delmond I, Niittyla T, Sanchez P and Grant M (2002) Differential expression of genes encoding Arabidopsis phospholipases after challenge with virulent or avirulent Pseudomonas isolates. Mol Plant Microbe Interact 15:808-816.

Fahrendorf T and Dixon RA (1993) Stress responses in alfalfa (Medicago sativa L.). XVIII: Molecular cloning and expression of the elicitor-inducible cinnamic acid 4-hydroxylase cytochrome P450. Arch Biochem Biophys 305:509-515.

Feussner I and Wasternack C (2002) The lipoxygenase pathway. Annu Rev Plant Biol 53:275-97.

Forment J, Gadea J, Huerta L, Abizanda L, Agusti J, Alamar S, Alos E, Andres F, Arribas R, Beltran J et al. (2005) Development of a citrus genome-wide EST collection and cDNA microarray as resources for genomic studies. Plant Mol Biol 57:375-91.

Fridovich I (1991) Molecular oxygen; friend and foe. In: Pell EJ, Steffen KL (eds) Active Oxygen/Oxidative Stress and Plant Metabolism. Amer Soc Plant Physiol, Rockville, pp 1-5.

Furuichi T, Cunningham KW and Muto S (2001) A putative two pore channel AtTPC1 mediates $\mathrm{Ca}^{2+}$ flux in Arabidopsis leaf cells. Plant Cell Physiol 42:900-905.

Gabriel DW and Rolfe BG (1990) Working models of specific recognition in plant - Microbe interactions. Annu Rev Phytopath 28:365-391.

Gardner HW (1991) Recent investigations into the lipoxygenase pathway of plants. Biochim Biophys Acta 1084:221-239.

Gigon A, Matos AR, Laffray D, Zuily-Fodil Y and Pham-Thi AT (2004) Effect of drought stress on lipid metabolism in the leaves of Arabidopsis thaliana (ecotype Columbia). Ann Bot 94:345-51.

Gomi K, Itoh N, Yamamoto H and Akimitsu K (2002a) Characterization and functional analysis of class I and II acidic chitinase cDNA from rough lemon. J Gen Plant Pathol 68:191199.

Gomi K, Yamamoto H and Akimitsu K (2002b) Characterization of a lipoxygenase gene in rough lemon induced by Alternaria alternata. J Gen Plant Pathol 68:21-30.

Gozzo F (2003) Systemic acquired resistance in crop protection: From nature to a chemical approach. J Agric Food Chem 51:4487-4503.

Gravot A, Larbat R, Hehn A, Lievre K, Gontier E, Goergen JL and Bourgaud F (2004) Cinnamic acid 4-hydroxylase mechanism-based inactivation by psoralen derivatives: Cloning and characterization of a $\mathrm{C} 4 \mathrm{H}$ from a psoralen producing plant-Ruta graveolens-exhibiting low sensitivity to psoralen inactivation. Arch Biochem Biophys 422:71-80.

Griffiths A, Barry C, Alpuche-Soli AG and Grierson D (1999) Ethylene and developmental signals regulate expression of lipoxygenase genes during tomato fruit ripening. J Exp Bot 50:793-798.

Grun S, Lindermayr C, Sell S and Durner J (2006) Nitric oxide and gene regulation in plants. J Exp Bot 57:507-516.

Heath MC (2000) Hypersensitive response-related death. Plant Mol Biol 44:321-334.

Hildebrand DF, Hamilton-Kemp TR, Legg CS and Bookjans G (1989) Plant lipoxygenases: Occurrence, properties and possible functions. Curr Top Plant Biochem Physiol 7:201-219.
Hoeberichts FA, ten Have A and Woltering EJ (2003) A tomato metacaspase gene is upregulated during programmed cell death in Botrytis cinerea-infected leaves. Planta 217:517522.

Holland D, Ben-Hayyim G, Faltin Z, Camoin L, Strosberg AD and Eshdat Y (1993) Molecular characterization of saltstress-associated protein in citrus: Protein and cDNA sequence homology to mammalian glutathione peroxidases. Plant Mol Biol 21:923-927.

Huang X and Madan A (1999) CAP3: A DNA sequence assembly program. Genome Res 9:868-877.

Hwang EI, Kaneko M, Ohnishi Y and Horinouchi S (2003) Production of plant-specific flavanones by Escherichia coli containing an artificial gene cluster. Appl Environ Microbiol 69:2699-2706.

Jalloul A, Montillet JL, Assigbetsé K, Agnel JP, Delannoy E, Triantaphylides C, Daniel JF, Marmey P, Geiger JP and Nicole M (2002) Lipid peroxidation in cotton: Xanthomonas interactions and the role of lipoxygenases during the hypersensitive reaction. Plant J 32:1-12.

Kaiser WM, Weiner H, Kandlbimder A, Tsai C-B, Rockel P, Sonoda M and Planchet E (2002) Modulation of nitrate reductase: Some new insights, an unusual case and a potentially important side reaction. J Exp Bot 53:875-882.

Kaneko M, Hwang EI, Ohnishi Y and Horinouchi S (2003) Heterologous production of flavanones in Escherichia coli: Potential for combinatorial biosynthesis of flavonoids in bacteria. J Ind Microbiol Biotechnol 30:456-461.

Kawano T (2003) Roles of the reactive oxygen species-generating peroxidase reactions in plant defense and growth induction. Plant Cell Rep 21:829-837.

Kilili KG, Atanassova N, Vardanyan A, Clatot N, Al-Sabarna K, Kanellopoulos PN, Makris AM and Kampranis SC (2004) Differential roles of Tau class glutathione S-transferases in oxidative stress. J Biol Chem 279:24540-24551.

Klessig DF, Durner J, Noad R, Navarre DA, Wendehenne D, Kumar D, Zhou JM, Shah J, Zhang S, Kachroo P, et al. (2000) Nitric oxide and salicylic acid signaling in plant defenses. Proc Natl Acad Sci USA 97:8849-8855.

Kolomiets MV, Chen H, Gladon RJ, Braun EJ, and Hannapel DJ (2000) A leaf lipoxygenase of potato induced specifically by pathogen infection. Plant Physiol 124:1121-1130.

Kumar A and Ellis BE (2003) A family of polyketide synthase genes expressed in ripening Rubus fruits. Phytochemistry 62:513-526.

Lam E, Kato N and Lawton M (2001) Programmed cell death, mitochondria and the plant hypersensitive response. Nature 411:848-853.

Lamb C and Dixon RA (1997) The oxidative burst in plant disease resistance. Annu Rev Plant Physiol Plant Mol Biol 48:251275.

Laxalt AM, ter Riet B, Verdonk JC, Parigi L, Tameling WI, Vossen J, Haring M, Musgrave A and Munnik T (2001) Characterization of five tomato phospholipase D cDNAs: Rapid and specific expression of LePLDbeta1 on elicitation with xylanase. Plant J 26:237-247.

Lea PJ (1999) Nitrogen metabolism. In: Lea PJ and Leegood RC (eds) Plant Biochemistry and Molecular Biology. 2nd edition. Wiley, Chichester, pp 163-192. 
Lee HY, Bahnb SC, Shinb JS, Hwanga I, Backc K, Doellingd JH and Ryu SB (2005) Multiple forms of secretory phospholipase A2 in plants. Prog Lipid Res 44:52-67.

Lee SC and Hwang BK (2005) Induction of some defense-related genes and oxidative burst is required for the establishment of systemic acquired resistance in Capsicum annuиm. Planta 221:790-800.

Leubner-Metzger G and Meins FJr (1999) Function and regulation of plant b-1,3-glucanases (PR-2). In: Datta SK and Muthukrishnan S (eds) Pathogenesis Related Proteins in Plants, CRC Press, Boca Raton, pp 49-76.

Maser P, Thomine S, Schroeder JI, Ward JM, Hirschi K, Sze H, Talke IN, Amtmann A, Maathuis FJM, Sanders D, et al. (2001) Phylogenetic relationships within cation transporter families of Arabidopsis. Plant Physiol 126:1646-1667.

McGonigle B, Keeler SJ, Lau SM, Koeppe MK and O'Keefe DP (2000) A genomics approach to the comprehensive analysis of the glutathione S-transferase gene family in soybean and maize. Plant Physiol 124:1105-1120.

Meijer HJ and Munnik T (2003) Phospholipid-based signaling in plants. Annu Rev Plant Biol 54:265-306.

Melan MA, Dong X, Endara ME, Davis KR, Ausubel FM and Peterman TK (1993) An Arabidopsis thaliana lipoxygenase gene can be induced by pathogens, abscisic acid, and methyl jasmonate. Plant Physiol 101:441-50.

Melillo MT, Leonetti P, Bongiovanni M, Castagnone-Sereno P and Bleve-Zacheo T (2006) Modulation of reactive oxygen species activities and $\mathrm{H}_{2} \mathrm{O}_{2}$ accumulation during compatible and incompatible tomato - Root-knot nematode interactions. New Phytol 170:501-512.

Métraux J-P (2002) Recent breakthroughs in the study of salicylic acid biosynthesis. Trends Plant Sci 7:332-334.

Michard E, Lacombe B, Poree F, Mueller-Roeber B, Sentenac H, Thibaud JB and Dreyer I (2005) A unique voltage sensor sensitizes the potassium channel AKT2 to phosphoregulation. J Gen Physiol 126:605-617.

Milla MAR, Maurer A, Rodriguez Huete A and Gustafson JP (2003) Glutathione peroxidase genes in Arabidopsis are ubiquitous and regulated by abiotic stresses through diverse signaling pathways. Plant J 36:602-615.

Montillet JL, Chamnongpol S, Rusterucci C, Dat J, van de Cotte B, Agnel JP, Battesti C, Inze D, Van Breusegem F and Triantaphylides C (2005) Fatty acid hydroperoxides and $\mathrm{H}_{2} \mathrm{O}_{2}$ in the execution of hypersensitive cell death in tobacco leaves. Plant Physiol 138:1516-1526.

Morant M, Bak S, Moller BL and Werck-Reichhart D (2003) Plant cytochromes P450: Tools for pharmacology, plant protection and phytoremediation. Curr Opin Biotechnol 14:151-162.

Moriguchi T, Kita M, Tomono Y, EndoInagaki T and Omura M (1999) One type of chalcone synthase gene expressed during embryogenesis regulates the flavonoid accumulation in citrus cell cultures. Plant Cell Physiol 40:651-655.

Narvaez-Vasquez J, Florin-Christensen J and Ryan CA (1999) Positional specificity of a phospholipase A activity induced by wounding, systemin, and oligosaccharide elicitors in tomato leaves. Plant Cell 11:2249-2260.

Neill SJ, Desikan R, Clarke A, Hurst RD and Hancock JT (2002) Hydrogen peroxide and nitric oxide as signaling molecules in plants. J Exp Bot 53:1237-1247.
Nelson DE, Raghothama KG, Singh NK, Hasegawa PM and Bressan RA (1992) Analysis of structure and transcriptional activation of an osmotin gene. Plant Mol Biol 19:577-588.

Ocampo CA, Moerschbacher B and Grambow HJ (1986) Increase lipoxygenase activity is involved in the hypersensitive response of wheat leaf cells infected with avirulent rust fungi or treated with fungal elicitor. Z Naturforsch 41c:558-563.

Ortega X and Perez LM (2001) Participation of the phosphoinositide metabolism in the hypersensitive response of Citrus limon against Alternaria alternata. Biol Res 34:43-50.

Parker JE and Colemann MJ (1997) Molecular intimacy between proteins specifying plant-pathogen recognition. Trends Biochem Sci 22:291-296.

Peng YL, Shirano Y, Ohta H, Hibino T, Tanaka K and Shibata D (1994) A novel lipoxygenase from rice. Primary structure and specific expression upon incompatible infection with rice blast fungus. J Biol Chem 269:3755-3761.

Pennell RI and Lamb C (1997) Programmed cell death in plants. Plant Cell 9:1157-1168.

Pontier D, Mittler R and Lam E (2002) Mechanism of cell death and disease resistance induction by transgenic expression of bacterio-opsin. Plant J 30:499-509.

Rance I, Fournier J and Esquerre-Tugaye MT (1998) The incompatible interaction between Phytophthora parasitica var. nicotianae race $\mathrm{O}$ and tobacco is suppressed in transgenic plants expressing antisense lipoxygenase sequences. Proc Natl Acad Sci USA 95:6554-6559.

Rebecchi MJ and Pentyala SN (2000) Structure, function, and control of phosphoinositide-specific phospholipase C. Physiol Rev 80:1291-1335.

Rentel MC, Lecourieux D, Ouaked F, Usher S, Petersen L, Okamoto H, Knight H, Peck SC, Grierson CS, Hirt H, et al. (2004) OXI1 kinase is necessary for oxidative burstmediated signaling in Arabidopsis. Nature 427:858-861.

Robinson DS, Wu Z, Domoney C and Casey R (1995) Lipoxygenase and quality of foods. Food Chem 54:33-43.

Sanders D, Pelloux J, Brownlee C and Harper JF (2002) Calcium at crossroads of signaling. Plant Cell 14 (supplement):S401-S417.

Sappl PG, Onate-Sanchez L, Singh KB and Millar AH (2004) Proteomic analysis of glutathione S-transferases of Arabidopsis thaliana reveals differential salicylic acid-induced expression of the plant-specific phi and tau classes. Plant Mol Biol 54:205-219.

Sato F, Kitajima S, Koyama T and Yamada Y (1996) Ethylene-induced gene expression of osmotin-like protein, a neutral isoform of tobacco PR-5, is mediated by the AGCCGCC cis-sequence. Plant Cell Physiol 37:249-255.

Scheel D (1998) Resistance response physiology and signal transduction. Curr Opin Plant Biol 1:305-310.

Shah J (2003) The salicylic acid loop in plant defense. Curr Opin Plant Biol 6:365-371.

Shah J and Klessig DF (1999) Salicylic acid: Signal perception and transduction. In: Libbenga K, Hall M and Hooykaas PJJ (eds) Biochemistry and Molecular Biology of Plant Hormones. Elsevier, London, v 33, pp 513-541.

Siedow JN (1991) Plant lipoxygenases: Structure and function. Annu Rev Plant Physiol Plant Mol Biol 42:145-188.

Skinner DZ and Baek K-H (2006) Differential expression of manganese superoxide dismutase sequence variants in near iso- 
genic lines of wheat during cold acclimation. Plant Cell Rep 25:223-230.

Smirnoff N (1993) The role of active oxygen in the response to water deficit and desiccation. New Phytol 125:27-58.

Sofo A, Dichio B, Xiloyannis C and Masia A (2004) Lipoxygenase activity and proline accumulation in leaves and roots of olive trees in response to drought stress. Physiol Plant 121:58-65.

Spiteller G (2003) The relationship between changes in the cell wall, lipid peroxidation, proliferation, senescence and cell death. Physiol Plant 119:5-155.

Stout MJ, Thaler JS and Thomma BPHJ (2006) Plant-mediated interactions between pathogenic microorganisms and herbivorous arthropods. Annu Rev Entomol 51:663-689.

Tiffin P (2004) Comparative evolutionary histories of chitinase genes in the genus Zea and family Poaceae. Genetics 167:1331-1340.

Tognolli M, Penel C, Greppin H and Simon P (2002) Analysis and expression of the class III peroxidase large gene family in Arabidopsis thaliana. Gene 288:129-138.

Ursini F, Maiorino M and Gregolin C (1985) The selenoenzyme phospholipid hydroperoxide glutathione peroxidase. Biochim Biophys Acta 839:62-70.

Utz PJ and Anderson P (2000) Life and death decisions: Regulation of apoptosis by proteolysis of signaling molecules. Cell Death Differ 7:589-602.

Vercammen D, van de Cotte B, De Jaeger G, Eeckhout D, Casteels P, Vandepoele K, Vandenberghe I, Van Beeumen J, Inze D and Van Breusegem F (2004) Type II metacaspases Atmc 4 and Atmc9 of Arabidopsis thaliana cleave substrates after arginine and lysine. J Biol Chem 279:45329-45336.

Wang X (2002) Phospholipase D in hormonal and stress signaling. Curr Opin Plant Biol 5:408-414.

Wang X (2004) Lipid signaling. Curr Opin Plant Biol 7:329-336.

Wang X (2005) Regulatory functions of phospholipase D and phosphatidic acid in plant growth, development, and stress responses. Plant Physiol 139:566-573.

Wang YJ, Yu JN, Chen T, Zhang ZG, Hao YJ, Zhang JS and Chen SY (2005) Functional analysis of a putative $\mathrm{Ca}^{2+}$ channel gene TaTPC1 from wheat. Jour Exp Bot 56:3051-3060.

White PJ (2000) Calcium channels in higher plants. Biochim Biophys Acta 1465:171-189.
Winkel-Shirley B (2001) Flavonoid biosynthesis. A colorful model for genetics, biochemistry, cell biology, and biotechnology. Plant Physiol 126:485-493.

Wirdnam C, Motoyama A, Arn-Bouldoires E, van Eeden S, Iglesias A and Meins F Jr (2004) Altered expression of an ankyrin-repeat protein results in leaf abnormalities, necrotic lesions, and the elaboration of a systemic signal. Plant Mol Biol 56:717-730.

Yalpani N, Leon J, Lawton MA and Raskin I (1993) Pathway of salicylic acid biosynthesis in healthy and virus-inoculated tobacco. Plant Physiol 103:315-321.

Yamamoto A, Katou S, Yoshioka H, Doke N and Kawakita H (2003) Nitrate reductase, a nitric oxide-producing enzyme: Induction by pathogen signals. J Gen Plant Pathol 69:218229.

Yamamoto H and Tani T (1986) Possible involvement of lipoxygenase in the mechanism of resistance of oats Avena sativa to Puccinia coronata pv. avenae. J Phytopathol 116:329337.

Yang J, Huang J, Gu H, Zhong Y and Yang Z (2002) Duplication and adaptive evolution of the chalcone synthase genes of Dendranthema (Asteraceae). Mol Biol Evol 19:1752-1759.

Zhao J, Davis LC and Verpoorte R (2005) Elicitor signal transduction leading to production of plant secondary metabolites. Biotechnol Adv 23:283-333.

Zhu B, Chen THH and Li PH (1995) Activation of two osmotinlike protein genes by abiotic stimuli and fungal pathogen in transgenic potato plants. Plant Physiol 108:929-937.

\section{Internet Resources}

CitEST (Citrus ESTs database), http://biotecnologia. centrodecitricultura.br (June 25, 2006).

ClustalW program, http://www.ebi.ac.uk/clustalw/ (November 13, 2006).

NCBI, http://www.ncbi.nlm.nih.gov/ (November 6, 2006).

\section{Supplementary Material}

The following online material is available for this article:

Table S1

This material is available as part of the online article from http://www.scielo.br/gmb.

Associate Editor: Raquel Luciana Boscariol-Camargo 
Table S1 - Description of citrus ESTs enconding proteins involved in HR.

\begin{tabular}{|c|c|c|c|c|c|c|}
\hline \multirow[t]{2}{*}{ Gene product and organism } & \multirow[t]{2}{*}{$\begin{array}{l}\text { Accession } \\
\text { Number }\end{array}$} & \multirow{2}{*}{$\begin{array}{c}\text { Best } \\
e- \\
\text { value }\end{array}$} & \multirow[t]{2}{*}{$\begin{array}{c}\text { Best } \\
\text { Similarity }\end{array}$} & \multirow[t]{2}{*}{$\begin{array}{l}\text { Number } \\
\text { of reads }\end{array}$} & \multicolumn{2}{|c|}{$\begin{array}{c}\text { Number } \\
\text { Contigs* Singleton }\end{array}$} \\
\hline & & & & & & \\
\hline \multicolumn{7}{|l|}{ Calcium channels } \\
\hline $\begin{array}{l}\text { two-pore calcium channel[}[A \text {. } \\
\text { thaliana }]\end{array}$ & gil14349162 & 0.0 & $371 / 432$ & 10 & $1(\mathrm{C} 1)$ & 0 \\
\hline $\begin{array}{l}\text { two-pore calcium channel }[N \text {. } \\
\text { tabacum }]\end{array}$ & gil46275794 & $9 e-52$ & $133 / 170$ & 5 & $1(\mathrm{C} 2)$ & 2 \\
\hline
\end{tabular}

\section{Chalcone synthase}

chalcone synthase $[$ C. sinensis $]$

$\begin{array}{llllll}\text { BAA81664 } & 0.0 & 391 / 391 & 146 & 3(\mathrm{C} 1 ; & 8\end{array}$

$\mathrm{C} 3$; 44$)$

$\begin{array}{lllllll}\text { chalcone synthase }[\text { Betula pendula] } & \text { CAA71904 } & \text { 2e-40 } & 89 / 108 & 3 & 1 & 1\end{array}$

chalcone synthase [Aubrieta

$\begin{array}{llllll}\text { AAG43406 } & 1 \mathrm{e}-25 & 86 / 146 & 1 & 0 & 1\end{array}$

deltoidea $]$

chalcone synthase $3[$ Ruta

Q9FSB7 3e-17 106/239

graveolens]

chalcone synthase

$\begin{array}{llllll}\text { AAM46963 } & 7 \mathrm{e}-19 & 43 / 46 & 1 & 0 & 1\end{array}$

[Chrysanthemum indicum]

\section{Chitinase}

Acidic class II chitinase $[C$.

$\begin{array}{lllll}\text { BAC20285 } & \text { e-169 } & 282 / 293 & 185 & 6\end{array}$

jambhiri]

Acidic class I chitinase $[C$.

BAC20284 e-177 289/300

154

4

6

jambhiri]

Bulb chitinase-1 [Tulipa bakeri]

BAA88408 e-110 230/279

7

1

0 


\begin{tabular}{|c|c|c|c|c|c|}
\hline Chitinase $[C$. sinensis $]$ & CAA93847 & e-178 & $292 / 292$ & 64 & 3 \\
\hline$\underline{\text { Chitinase }[\text { Hevea brasiliensis] }}$ & CAA09110 & e-139 & $269 / 302$ & 6 & 1 \\
\hline Chitinase CHI1 [C. sinensis] & AAC35981 & $4 e-75$ & $166 / 232$ & 13 & 4 \\
\hline Chitinase-like protein [G.hirsutum] & AAQ56598 & e-164 & $291 / 322$ & 18 & 3 \\
\hline Chitinase/lysozyme [N.tabacum] & CAA55128 & $4 \mathrm{e}-48$ & $126 / 195$ & 4 & 1 \\
\hline Putative chitinase $[$ A. thaliana $]$ & CAA19698 & $9 \mathrm{e}-45$ & $145 / 220$ & 3 & 1 \\
\hline Putative class I chitinase $[A$. & AAG48821 & e-149 & $277 / 321$ & 115 & 3 \\
\hline thaliana] & & & & & \\
\hline Receptor-like kinase CHRK1 $[N$. & AAD52097 & $6 e-76$ & $299 / 484$ & 9 & 2 \\
\hline
\end{tabular}

\section{Chorismate mutase}

putative chorismate mutase [Fagus

$\begin{array}{llllll}\text { ABA54871 } & 8 \mathrm{e}-122 & 265 / 326 & 7 & 1(\mathrm{C} 5) & 0\end{array}$

sylvatica

putative chorismate mutase $[A$.

AAC73018 5e-100

$219 / 290$

4

$1(\mathrm{C} 4)$

thaliana]

chorismate mutase ATCM2 $[A$.

NP_196648 4e-65 145/182

2

0

thaliana].

chorimate mutase [L. esculentum]

AAD48923 4e-15

$49 / 60$

1

$0 \quad 1$

chorismate mutase-T [A. thaliana]

BAB10786 1e-35 97/137

1

0

1

chorismate mutase $[$ A. thaliana $]$

AAM61395 3e-107 270/370

2 (C6;

1

C7)

\section{Cinnamic acid 4-hydroxylase}

cinnamate 4-hydroxylase CYP73

$\begin{array}{llllll}\text { AAF66066 } & 0.0 & 485 / 485 & 59 & 2(\mathrm{C} 1 ; & 2\end{array}$

[C. sinensis]

C3)

Cinnamic acid 4-hydroxylase $[M$. 
sativa]

\section{Glutathione peroxidases}

Phospholipid hydroperoxide

$\begin{array}{llllll}\text { CAE46896 } & 1 \mathrm{e}-91 & 167 / 167 & 13 & 1 & 0\end{array}$

glutathione peroxidase $[C$.

sinensis]

$49 \quad 1$

2

phospholipid hydroperoxide

glutathione peroxidase (PHGPx)

(Salt-associated protein) $[C$.

sinensis]

Phospholipid glutathione

CAA04142 2e-89 193/246 28

28

2

0

peroxidase [Pisum sativum]

Phospholipid hydroperoxide

AAL40914 4e-76 148/164 14

2

0

glutathione peroxidase

[Momordica charantia]

Putative phospholipid

CAD31839 8e-24 83/137

3

0

hydroperoxide glutathione

peroxidase [Cicer arietinum]

Glutathione peroxidase, putative

NP_564813 2e-69

$139 / 153$

5

0

[A. thaliana]

Putative glutathione peroxidase $\left[\begin{array}{llll}A . & \text { AAM67012 } & 5 \mathrm{e}-68 & 145 / 169\end{array}\right.$

thaliana]

Glutathione peroxidase, putative

NP_194915 6e-86

$168 / 184$

6

1

0

[A. thaliana] 
Glutathione transferases

Glutathione S-transferase GST 22 AAG34812 $\quad 3$ e-89 $\quad 181 / 209 \quad 51 \quad 6 \quad 6 \quad 1$

[G. $\max ]$

Glutathione S-transferase GST $14 \quad$ AAG34804 $\quad$ 2e-66 $145 / 220 \quad 29 \quad 3 \quad 1$

[G. $\max ]$

$\begin{array}{lllllll}\text { Glutathione S-transferase GST } 23 & \text { AAG34813 } & 5 \mathrm{e}-35 & 79 / 85 & 2 & 1 & 0\end{array}$

[G. $\max ]$

Glutathione S-transferase T3

AAG16758 4e-82 173/223 29

5

LeGST-T3 [L. esculentum]

Glutathione S-transferase [Pisum

BAC81649 8e-97 196/236

10

3

0

sativum]

Glutathione transferase [Carica

CAA04391 2e-82 159/180

6

2

0

papaya]

Glutathione S-transferase

$\begin{array}{llllll}\text { AAF65767 } & 3 \mathrm{e}-79 & 166 / 212 & 45 & 2 & 0\end{array}$

[Euphorbia esula]

Glutathione S-transferase [E.

AAF72197 6e-89 188/210

15

0

esula]

Glutathione S-transferase 2

AAF22518 2e-85 175/215

37

2

0

[Papaver somniferum]

Glutathione S-

CAI48072 e-100 193/220

13

2

0

transferase/peroxidase [Capsicum

chinense]

Glutathione S-transferase [Thlasp

AY917145 5e-174 204/240

13

0

caerulescens]

Glutathione transferase AtGST 10

BAB09723 4e-99 208/237

3

1 


\section{[A. thaliana $]$}

Glutathione S-transferase [A.

AAG30140 6e-77 164/215

6

0

thaliana]

Putative glutathione S-transferase

AAM64426 5e-62 153/205

5

0

[A. thaliana]

Putative glutathione S-transferase

XP_470193 3e-71 163/218

14

0

[O. sativa]

Putative glutathione transferase $[O$.

BAD28950 7e-22 52/60

2

0

sativa]

Glutathione S-transferase GST 9

AAG34817 3e-31 85/110

5

0

[Zea mays]

Putative glutathione S-transferase

AAM34480 4e-13 42/48

2

0

[Phaseolus acutifolius]

Glutathione S-transferase

BAC21263 5e-66 153/189

4

1

0

[Cucurbita maxima]

\section{Isochorismate synthase}

isochorismate synthases, putative

ABE91019 1e-81 185/202

4

$1(\mathrm{C} 2)$

0

[M. truncatula].

isochorismate synthase $[C$.

AAW66457 3e-65 175/244

2

1

0

annuum]

Isochorismate synthase, chloroplast

Q97PC0

$1 \mathrm{e}-58$

$163 / 246$

1

0

1

precursor [Catharanthus roseus]

\section{Lipoxygenase}

Lipoxygenase [Fragaria $\mathrm{x}$

CAE17327 e-126 219/255

4

1

1

ananassa] 


$\begin{array}{lcccccc}\text { Lipoxygenase [Corylus avellana] } & \text { CAD10740 } & 4 \mathrm{e}-76 & 158 / 187 & 1 & 0 & 1 \\ \text { Lipoxygenase [Solanum } & \text { CAA65268 } & 0.0 & 622 / 803 & 29 & 3 & 0 \\ \text { tuberosum] } & & & & & \\ \text { Lipoxygenase [C. jambhiri] } & \text { BAB84352 } & 0.0 & 762 / 904 & 226 & 6(\mathrm{C} 11) & 10 \\ \text { Lipoxygenase 1 [Sesbania } & \text { CAC43237 } & 0.0 & 803 / 950 & 9 & 1 \text { (C7) } & 0 \\ \text { rostrata] } & & & & & \\ \text { Lipoxygenase 1 [Prunus dulcis] } & \text { CAD10779 } & 8 \mathrm{e}-05 & 44 / 74 & 2 & 0 & 2 \\ \text { Lipoxygenase 2 [Zantedeschia } & \text { AAG18376 } & 0.0 & 690 / 819 & 27 & 2(\mathrm{C} 3) & 0 \\ \text { aethiopica] } & & & & & & \\ \text { Lipoxygenase 2 [Nicotiana } & \text { AAP83137 } & 4 \mathrm{e}-83 & 207 / 289 & 25 & 3\end{array}$

\begin{tabular}{lllllll}
\hline Metacaspases & & & & & \\
metacaspase 1 [A. thaliana $]$ & AAP84706 & $\mathrm{e}-104$ & $202 / 243$ & 9 & 2 & 0 \\
metacaspase $3[$ A. thaliana $]$ & AAP44516 & $6 \mathrm{e}-38$ & $125 / 226$ & 1 & 0 & 1 \\
metacaspase 7 [A. thaliana $]$ & AAP84710 & $4 \mathrm{e}-88$ & $206 / 267$ & 5 & 1 & 0 \\
metacaspase 1 [L. esculentum] & AAM51555 & $3 \mathrm{e}-84$ & $181 / 234$ & 2 & 0 & 2 \\
putative metacaspase $[$ O. sativa $]$ & AAR06365 & $4 \mathrm{e}-20$ & $81 / 150$ & 1 & 0 & 1
\end{tabular}

\section{NADPH}

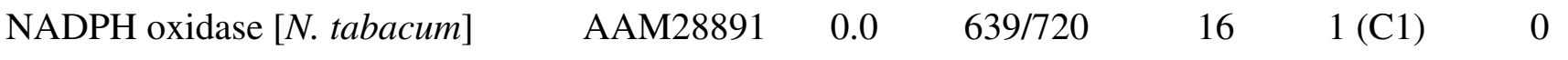

FRO2-like protein; NADPH

$\begin{array}{llllll}\text { BAA98161 e-104 } 235 / 310 & 4 & 1(\mathrm{C} 2) & 0\end{array}$

oxidase-like [A. thaliana]

ferric reductase-like

NP_199785 e-152 317/401 $\quad 5 \quad 1(\mathrm{C} 3) \quad 1$

transmembrane component family

protein $[$ A. thaliana $]$

FRO2 homolog [A. thaliana]

BAB08722 1e-79 178/272


respiratory burst oxidase homolog

BAC56865 3e-69 81/119

1

0

1

[N. benthamiana]

\begin{tabular}{|c|c|c|c|c|c|c|}
\hline \multicolumn{7}{|l|}{ Nitrate reductase } \\
\hline nitrate reductase [NADH] (NR) & P36859 & 0.0 & $495 / 567$ & 11 & $1(\mathrm{C} 10)$ & 0 \\
\hline \multicolumn{7}{|l|}{ [Petunia $\mathrm{x}$ hybrida] } \\
\hline nitrate reductase [Tilia & AAN15927 & $2 \mathrm{e}-152$ & $294 / 337$ & 3 & $1(\mathrm{C} 11)$ & 0 \\
\hline \multicolumn{7}{|l|}{ platyphyllos] } \\
\hline nitrate reductase [Ricinus & AAG30576 & $1 e-85$ & $179 / 211$ & 6 & $1(\mathrm{C} 7)$ & 0 \\
\hline \multicolumn{7}{|l|}{ communis] } \\
\hline nitrate reductase [Brassica napus] & BAA07395 & $4 \mathrm{e}-23$ & $60 / 89$ & 1 & 0 & 1 \\
\hline
\end{tabular}

PR-5-like protein (Osmotin, Permeatin or Thaumatin)

PR-5-like protein [A. thaliana $]$

AAM44961 1e-103 218/296

2

0

PR-5-like protein [A. thaliana]

NP_173261 1e-109 208/243

13

0

PR-5-like protein [A. thaliana]

BAB11214 5e-75 158/203

3

0

PR-5-like protein [A. thaliana]

AAM64698 1e-101 193/231

8

0

PR-5-like protein [Citrus sinensis]

AAC02549 2e-63 111/114

3

0

PR-5-like protein OLP1 $[L$.

Q41350 1e-117 204/235 25

0

esculentum]

PR-5-like protein Mdtl1 [Malus x

$\begin{array}{lllll}\text { AAC } 36740 & 4 \mathrm{e}-98 & 191 / 235 & 3 & 1\end{array}$

domestica]

PR-5-like proteinVVTL1 [Vitis

$\begin{array}{lllll}\text { AAB61590 } & 9 \mathrm{e}-89 & 177 / 227 & 2 & 1\end{array}$

vinifera]

PR-5-like protein [Brassica rapa]

T14428 6e-75 152/188

1

0

1

PR-5-like protein [Helianthus

AAM21199 9e-84 150/188

1

0 
annuus]

PR-5-like protein SE39b [N.

$\begin{array}{lllll}\text { BAA74546 } & 1 \mathrm{e}-83 & 161 / 210 & 2 & 0\end{array}$

tabacum]

Peroxidases

thioredoxin peroxidase [N.

CAC84143 e-113 234/278

45

3

2

tabacum]

apoplastic anionic guaiacol

AAL92037 e-129 282/352

47

4

1

peroxidase [G. hirsutum]

peroxidase [Spinacia oleracea]

CAA71492 e-111 246/314

23

2

0

ascorbate peroxidase [Ipomoea

AAP42501 e-126 231/250

41

4

0

batatas]

peroxidase [N. tabacum]

$\begin{array}{llllll}\text { AAK52084 } & \text { e-125 } & 271 / 354 & 16 & 1 & 0\end{array}$

peroxidase precursor [Quercus

AAR31106 e-92 189/218 12

suber]

putative peroxidase $[$ A. thaliana $]$

AAO50583 e-117 233/250

20

0

cationic peroxidase isozyme $40 \mathrm{~K}$

BAA07664 e-98 240/321

53

0

precursor [N. tabacum]

class III peroxidase [G. hirsutum]

e-152

$291 / 318$

11

2

0

putative peroxidase $[$ A. thaliana $]$

$\begin{array}{llllll}\text { AAM20043 } & \text { e-129 } & 254 / 294 & 28 & 1 & 0\end{array}$

bacterial-induced peroxidase

AAD43561 e-136 272/320

22

1

1

precursor [G. hirsutum]

peroxidase [Populus balsamifera

CAA66037 e-120 258/343

13

3

0

subsp. Trichocarpa]

peroxidase ATP2a [A. thaliana]

CAA66863 e-126 244/281

21

2

0

putative L-ascorbate peroxidase $[A$.

BAC42431 9e-53 133/170

64

1 
thaliana]

peroxidase precursor [G. $\max ]$

$\begin{array}{llllll}\text { AAD11482 } & \text { e-127 } & 267 / 316 & 10 & 1 & 1\end{array}$

putative ascorbate peroxidase $[A$.

AAF23294 6e-98 183/202

7

0

thaliana]

putative trypanothione-dependent

AAP50932 1e-86 248/406

$31(\mathrm{C} 22)$

0

peroxidase [O. sativa (japonica

cultivar-group)]

L-ascorbate peroxidase $1 b$

NP_187575 e-125 230/248

21

0

(APX1b) [A. thaliana $]$

ascorbate peroxidase pirl|T09845

AAB52954 e-119 217/223

$31(\mathrm{C} 65)$

0

L-ascorbate peroxidase (EC

1.11.1.11), glyoxysomal - upland

cotton

secretory peroxidase $[N$. tabacum $]$

$\begin{array}{llllll}\text { AAD33072 } & \text { e-133 } & 246 / 257 & 16 & 1 & 5\end{array}$

chloroplast stromal ascorbate

$\begin{array}{llllll}\text { AAS55853 } & \text { e-165 } & 321 / 369 & 10 & 1 & 0\end{array}$

peroxidase [Vigna unguiculata]

Peroxidase pirl|T10790 peroxidase

AAA99868 e-168 314/332

13

4

(EC 1.11.1.7) - upland cotton

At2g29670/T27A16.23 [A.

AAN18208 $\quad 6 e-88 \quad 212 / 278$

13

0

thaliana]

thylakoid-bound ascorbate

BAA78552 e-100 218/264

4

0

peroxidase [N. tabacum]

peroxidase precursor [Populus

BAA07240 e-127 263/327

7

0

kitakamiensis]

putative ascorbate peroxidase

CAB64343 e-138 297/347

5

2

0 
(TL29) [L. esculentum]

putative peroxidase $[$ A. thaliana $]$

putative peroxidase ATP2a $[A$.

AAM65003 3e-31 71/80

6

2

thaliana]

peroxidase ATP17a like protein $[A$.

BAD44575 1e-17 51/67

2

0

thaliana]

peroxidase $[P$. nigra $]$

BAA11853 e-120 253/325

2

peroxidase-like protein $[A$.

BAB08730 1e-25 62/67

1

1

thaliana]

peroxisomal ascorbate peroxidase

BAB64351 1e-18 52/66

1

0

1

[Cucurbita cv. Kurokawa

Amakuri]

glutathione peroxidase, putative $\left[\begin{array}{llll}A . & \text { NP_564813 } & 1 \mathrm{e}-15 & 41 / 43\end{array}\right.$

1

0

1

thaliana $]$

peroxidase C2 precursor-like

AAN15499 3e-14 42/75

1

0

1

protein [A. thaliana]

glutathione transferase [Carica

CAA04391 8e-62 130/160

0

1

papaya]

korean-radish isoperoxidase

CAA62597 1e-42 130/233

0

1

[Raphanus sativus]

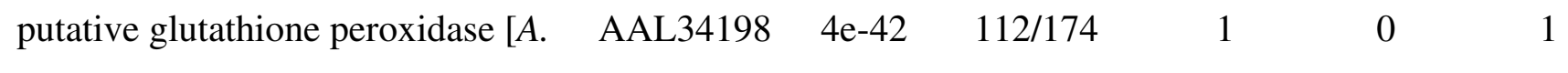

thaliana]

peroxidase [Linum usitatissimum]

$\begin{array}{llllll}\text { AAB02926 } & 1 \mathrm{e}-72 & 162 / 213 & 1 & 0 & 1\end{array}$

putative peroxidase $[$ A. thaliana $]$

CAB39666 3e-20 61/150

1

0

1

glutathione peroxidase (EC

S33618 5e-30 42/44

1

0

1 
1.11.1.9) - sweet orange

ascorbate peroxidase [Pimpinella

e-101 196/250

0

1

brachycarpa]

PER7_ARATH Peroxidase 7

Q9SY33 4e-58 149/214

0

1

precursor (Atperox P7)

cytosolic ascorbate peroxidase

AAB94574 2e-28 54/98

1

0

1

[Fragaria $\mathrm{x}$ ananassa]

putative thioredoxin peroxidase $[O$.

BAD28826 2e-26 64/73

0

1

sativa (japonica cultivar-group)]

peroxidase ATP1a $[$ A. thaliana $]$

$\begin{array}{llllll}\text { CAA66862 } & 2 \mathrm{e}-29 & 112 / 199 & 1 & 0 & 1\end{array}$

peroxidase (EC 1.11.1.7), anionic,

B56555 3e-59 139/190

1

$0 \quad 1$

precursor - wood tobacco

peroxidase [A. thaliana]

BAB10239 e-70 176/260

0

1

thylakoid-bound L-ascorbate

AAC19393 e-34 70/94

0

1

peroxidase precursor

[Mesembryanthemum

crystallinum]

thylakoid-bound ascorbate

BAA12029 e-60 130/146

$130 / 146$

0

1

peroxidase [Cucurbita $\mathrm{cv}$.

Kurokawa Amakuri]

thioredoxin peroxidase [Secale

AAC78473 4e-19 71/142

1

0

1

cereale]

peroxidase [A. thaliana]

$\begin{array}{llllll}\text { CAA66957 } & 2 \mathrm{e}-43 & 89 / 140 & 1 & 0 & 1\end{array}$

putative peroxidase [O. sativa

BAB39281 2e-63 150/216

0

1

(japonica cultivar-group)] 
ascorbate peroxidase [O. sativa

BAB17666 2e-22 67/142

1

0

1

(japonica cultivar-group)]

putative ascorbate peroxidase

AAP72143 3e-30 67/75

1

0

1

APX4 [A. thaliana]

peroxidase [N. tabacum]

BAA82306 8e-71 155/235

1

0

1

PE48_ARATH Putative Peroxidase

O81755

$6 e-20$

$61 / 77$

1

0

1 48 (Atperox P48)

\section{Phenylalanine ammonia-lyase}

phenylalanine-ammonia lyase $[C$.

CAB42794

$0.0 \quad 708 / 713$

$69 \quad 1(\mathrm{C} 3)$

2

clementina $x$ C. reticulata]

phenylalanine ammonia-lyase $[C$.

Q42667

$0.0 \quad 715 / 722$

$23 \quad 1(\mathrm{C} 8)$

3

limon]

phenylalanine ammonia-lyase

$\begin{array}{llllll}\mathrm{ABI} 33979 & 0.0 & 356 / 380 & 4 & 1(\mathrm{C} 9) & 0\end{array}$

[Jatropha curcas]

phenylalanine ammonia-lyase

AAX18625 2e-107 200/208

$2 \quad 1(\mathrm{C} 10)$

0

[Nerium oleander]

phenylalanine ammonia-lyase 1

AAK62030 e-116 231/270

1

0

1

[Manihot esculenta]

phenylalanine ammonia-lyase

P45730 9e-55 110/145

1

0

1

[Populus trichocarpa]

\section{Phospholipases}

putative phospholipase A2 $[O$.

XP_468549 6e-47 98/120

4

1

0

sativa]

phosphoinositide-specific

AAB03258

0.0

$512 / 602$

20

1

0 
phospholipase C P13 [G. max]

putative phospholipase $\mathrm{C}[A$.

AAC32238 e-127 229/276

2

0

thaliana]

phospholipase $\mathrm{C}$ [O. sativa]

CAC81703 e-101 94/118

4

0

4

phospholipase C [A. thaliana]

NP_175685 e-108 200/222

1

$\begin{array}{ll}0 & 1\end{array}$

1-phosphatidylinositol-4,5-

CAA72681 e-147 273/306

1

0

bisphosphate phosphodiesterase $[N$.

rustica]

phosphoinositide-specific

gil7435171 5e-33 67/85

1

0

1

phospholipase C P12 [G. max]

phosphoinositide-specific

CAA65127 e-112 236/286

3

2

0

phospholipase C $[N$. rustica $]$

PLC [A. thaliana $]$

$\begin{array}{llllll}\text { AAL16172 } & 9 \mathrm{e}-92 & 178 / 204 & 1 & 0 & 1\end{array}$

ATPLC2 phospholipase C

NP_187464 2e-70 153/191

3

0

3

(ATPLC2) [A. thaliana]

phospholipase C2 [N. tabacum]

$\begin{array}{llllll}\text { AAF33824 } & 3 e-73 & 164 / 214 & 1 & 0 & 1\end{array}$

PLD [A. thaliana]

AAP42742 e-160 289/312

14

3

1

\section{Potassium channels}

CNGC1 [A. thaliana]

$\begin{array}{llllll}\text { NP_200125 } & 0.0 & 366 / 386 & 48 & 11 & 7\end{array}$

CNGC2 [G. hirsutum]

$\begin{array}{llllll}\text { AAX18166 } & 0.0 & 337 / 359 & 19 & 3 & 0\end{array}$

CNGC3 [A. thaliana]

NP_566075 e-100 204/245

2

0

2

CNGC4/ HLM1 [A. thaliana]

Q94AS9 6e-96 175/194

1

0

1

CNGC9 [A. thaliana]

NP_194785 1e-81 179/234

1

0

1

CNGC10 [A. thaliana $]$

NP_563625 1e-12 83/160

2

1

0

CNGC14 [A. thaliana]

NP_850056 2e-84 121/158

1

0

1 


\begin{tabular}{|c|c|c|c|c|c|c|}
\hline CNGC15 $[$ A. thaliana $]$ & NP_180393 & $3 e-60$ & $135 / 182$ & 2 & 0 & 2 \\
\hline CNGC17 $[$ A. thaliana $]$ & NP_194765 & $3 e-179$ & $347 / 394$ & 5 & 1 & 2 \\
\hline CNGC19 $[$ A. thaliana $]$ & NP_188396 & $2 \mathrm{e}-118$ & $254 / 311$ & 6 & 1 & 0 \\
\hline \multicolumn{7}{|l|}{ Superoxide dismutase } \\
\hline $\begin{array}{l}\text { SODM_HEVBR Superoxide } \\
\text { dismutase }[\mathrm{Mn}] \text {, mitochondrial }\end{array}$ & P35017 & e-105 & $199 / 231$ & 43 & 1 & 0 \\
\hline \multicolumn{7}{|l|}{ precursor S39492 superoxide } \\
\hline \multicolumn{7}{|l|}{ dismutase (EC 1.15.1.1) (Mn) } \\
\hline $\mathrm{Fe}$-superoxide dismutase precursor & AAL32441 & e-105 & $216 / 260$ & 58 & $3(\mathrm{C} 4)$ & 0 \\
\hline \multicolumn{7}{|l|}{$[$ M. sativa $]$} \\
\hline copper-zinc superoxide dismutase & AAW80437 & $2 e-55$ & $107 / 112$ & 3 & 1 & 0 \\
\hline \multicolumn{7}{|l|}{ [Nelumbo nucifera] } \\
\hline Fe-superoxide dismutase precursor & AAM61633 & $3 e-86$ & $177 / 205$ & 3 & $1(\mathrm{C} 3)$ & 0 \\
\hline \multicolumn{7}{|l|}{ [A. thaliana $]$} \\
\hline iron superoxide dismutase 3 [ $A$. & AAM63713 & $3 e-64$ & $139 / 178$ & 4 & $1(\mathrm{C} 7)$ & 0 \\
\hline \multicolumn{7}{|l|}{ thaliana] } \\
\hline superoxidase dismutase $[L$. & AAQ09007 & $3 e-77$ & $75 / 83$ & 4 & $1(\mathrm{C} 9)$ & 0 \\
\hline \multicolumn{7}{|l|}{ esculentum] } \\
\hline superoxide dismutase $[\mathrm{Fe}][L$. & CAE22480 & $3 e-76$ & $179 / 252$ & 2 & $1(\mathrm{C} 18)$ & 0 \\
\hline \multicolumn{7}{|l|}{ esculentum] } \\
\hline $\mathrm{Cu} / \mathrm{Zn}$-superoxide dismutase & AAK01931 & 3e-99 & $199 / 217$ & 7 & $2(\mathrm{C} 16)$ & 0 \\
\hline \multicolumn{7}{|l|}{ copper chaperone precursor $[G}$. \\
\hline $\max ]$ & & & & & & \\
\hline copper/zinc superoxide dismutase & AAQ14591 & $7 e-85$ & $151 / 152$ & 30 & $4(\mathrm{C} 19)$ & 1 \\
\hline
\end{tabular}


$\mathrm{Cu} / \mathrm{Zn}$ superoxide dismutase $\left[\begin{array}{lllllll}C . & \mathrm{CAA} 03881 & 5 \mathrm{e}-67 & 125 / 126 & 59 & 4(\mathrm{C} 12) & 5\end{array}\right.$ sinensis]

MnSOD [H. brasiliensis]

$\begin{array}{llllll}\text { CAB53458 } & 3 \mathrm{e}-16 & 40 / 48 & 1 & 0 & 1\end{array}$

manganese superoxide dismutase

AAB88870 1e-50 101/110

0

1

[Capsicum annuum]

putative $\mathrm{CuZn}$-superoxide

CAC33847 3e-69 116/127

20

2

dismutase [Populus tremula $\mathrm{x} P$.

tremuloides]

iron superoxide dismutase $3[A$.

AAC24834 2e-59

$142 / 200$

2

0

2

thaliana]

iron-superoxide dismutase [ $G$.

AAQ13492 3e-17 69/120

1

0

1

$\max ]$

copper/zinc superoxide dismutase

BAB78597 3e-13 38/40

1

0

1

[Bruguiera gymnorrhiza]

superoxide dismutase (EC

$$
\text { S03639 e-62 }
$$

$128 / 153$

1

0

1

1.15.1.1) (Mn) precursor - curled-

leaved tobacco

iron superoxide dismutase $3[A$.

BAB11186 2e-47 65/106

1

0

1

thaliana]

*Between parentheses are represented the contigs (C) commented in the Results and Discussion. As search for different proteins had been made in separate archives, different contigs (representing different proteins) can have the same number. 